\title{
Television, Tort Law, and Federalism ${ }^{\dagger}$
}

\author{
Robert M. O'Neil*
}

$\mathrm{T}$ HE IMPACT OF TELEVISTON upon the United States can hardly be doubted. The impact of tort law upon television has been widely discussed and often litigated. The impact of federal law upon the state tort law that creates the broadcaster's liability, however, has largely been neglected. This article will attempt to explore that impact. Before considering the strictly legal elements of the problem, those elements must be placed in perspective. It would be idle to discuss the impact of federalism at length if the broadcaster had no reason for concern about tort liability. There seems to be much cause for concern, however, whether or not the number of sucl cases has been increasing. ${ }^{1}$ The cases have recently been reported are more complex, and potential liability greater, than previously. At the same time, lowever, the limiting effects of federal law upon state tort claims in this area are increasingly apparent. It is the interaction between these two trends that forms the basic of this article.

The intriguingly tortious potential of television may best be illustrated through several recent cases. They serve to illustrate two points that that are of critical importance here: First, tort law has not kept pace with the clanging character of television and with the variety of situations that may lead to private litigation; and second, in part a consequence of the first, the results of the cases have varied widely from one state to another and even between courts within a single state.

Both difficulties are reflected in a jumble of cases that came in the wake of quiz show scandals. Shortly after the truth about "rigged" quiz

† The author is indebted to Mr. Frederick F. Gregory, a member of the third year class at Boalt Hall, for careful background research on some of the problems discussed here, and for many constructive and helpful suggestions.

* A.B., 1956, A.M., 1957, LL.B., 1961, Harvard University; Acting Associate Professor of Law, University of California, Berkeley.

1 Undoubtedly the number of reported suits against broadcasters has recently increased, as the cases cited herein will indicate. Spokesmen for the industry do not appear, however, to be concerned about any statistical increase in the volune of such bitigation. Letter from Reginald Geiser, Esq., Assistant Vice President, Employers Reinsurance Corp. (a major writer of broadcast defamation insurance) to the Author, March 4, 1965; Letter from Mortimer Weinbach, Vice President, American Broadcasting Co., to the Author, March 26, 1965; Letter from Ralph E. Goldberg, Law Department, Columbia Broadcasting System, to the Author, April 12, 1965. Yet there appears to have been sufficient concern to renew efforts in Congress for enactment of a law which would give broadcasters extensive immunities from state defamation law. See Broadcasting, March 8, 1965, p. 5 . 
programs came to light in 1958 and 1959, a number of lawsuits were filed by innocent contestants who had been duped, and whose reputations had suffered by their early defeats at the hands of primed "experts." The gist of these complaints, apparently, was that the plaintiffs' were either made to look stupid to the viewing public, or that the impression had been created they were somehow tied in with the crooked schemeall of which had enriched the sponsor and the producer and the network but not the plaintiff. The heart of the cases, then, was a claim that sounded very much like defamation. In the past the law of libel and slander had generally been able to accommodate novel ways of tarnishing an innocent man's reputation, whether out of malice or simply for sport. But in the quiz show cases, the New York courts have been and still are struggling to evolve a workable theory of defamation.

One trial court dismissed the whole idea on the ground that the defamation, if any, occurred not when the plaintiff appeared on the program but only when the truth was revealed, so that there was nothing in the broadcasts themselves which even resort to extrinsic facts would render defamatory. ${ }^{3}$ Other courts were a bit bolder. Two judges suggested, for example, that there might be recovery if the plaintiff could show special damages, but without explaining just how this claim differed in law from the ordinary libel claim for which an allegation of general damage would suffice. ${ }^{4}$ Only twice have these questions even gone to the Appellate Division, ${ }^{5}$ and never, apparently, to the New York Court of Appeals. $^{6}$

2 See, e.g., Morrison v. NBC, 40 Misc. 2d 876, 243 N.Y.S.2d 927 (Sup. Ct. 1963). Some of the suits also alleged breaches of implied contracts, but those claims were disposed of on traditional grounds.

3 E.g., Goldberg v. CBS, 25 Misc. 2d 129, 205 N.Y.S.2d 611 (Sup. Ct. 1960).

4 Morrison v. NBC, 40 Misc. 2d 876, 243 N.Y.S.2d 927 (Sup. Ct. 1963); Clark v. NBC, 28 Misc. 876, 243 N.Y.S.2d 927 (Sup. Ct. 1963).

5 Holt v. CBS, 22 App. Div. 2d 791, 253 N.Y.S.2d 1020 (1964); Clark v. NBC, 11 App. Div. 2d 642, 203 N.Y.S.2d 1009 (1960).

${ }^{6}$ For other plases of this litigation, all in the New York courts, see Friedlander v. NBC, 39 Misc. 2d 612, 241 N.Y.S.2d 477 (Sup. Ct. 1963) ; Clark v. NBC, 22 Misc. 2d 319, 195 N.Y.S.2d 940 (Sup. Ct. 1960), aff'd mem., 11 App. Div. 2d 642, 203 N.Y.S.2d 1009 (1960); Davidson v. NBC, 26 Misc. 2d 936, 204 N.Y.S.2d 532 (Sup. Ct. 1960); Goostree v. P. Lorillard Co., 26 Misc. 2d 109, 202 N.Y.S.2d 456 (Sup. Ct. 1960). Although inost of these suits were filed in 1958 or 1959, reference to the Holt and Friedlander cases indicates that the litigation has dragged on for several years. Some of these cases, indeed, are still pending. Most of the plaintiffs sued not only the network, but also the key station of the network over which the programs originated, the sponsors, the producers, and in at least one case a contestant whose collusive knowledge of the correct answers contributed to the plaintiff's lumiliation. In none of the reported decisions has the allocation of liability among these various defendants been considered.

The quiz show scandals had interesting repercussions and ramifications. For a lively

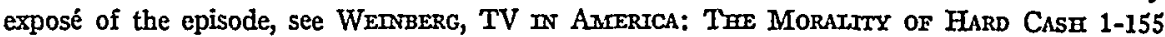
(1962). Thorough congressional investigation of the quiz show scandal led to rigorous 
The quiz show cases point out how difficult have been the recent problems in the field of defamation by television. At the same time there has been a good deal of activity in the invasion of privacy field, in directions which seem novel and potentially dangerous for the unwary broadcaster. At its inception the right to privacy afforded rather modest protections. ${ }^{7}$ Recently, however, there have been successful suits based upon the use of a name, ${ }^{8}$ or bits of a biography, ${ }^{9}$ or even indirectly disclosed identity ${ }^{10}$-not only for purposes of entertainment through drama or comedy, but even in the form of news reports. Perhaps most startling is a recent New York case enjoming, as an invasion of privacy, an unconsented account of the plaintiff's career less than twenty-four hours before the scheduled broadcast time. ${ }^{11}$

Novel interactions of tort law and television have occurred in other fields as well. We might consider for a moment the illustrative case of Bert Lahr and the voice of the talking duck. ${ }^{12}$ Several years ago the Adell Chemical Co. commissioned a series of TV cartoon commercials built around a duck that extolled, with diction quite remarkable for a duck, the virtues of Adell's Lestoil cleaning compound. The duck's voice sounded so strikingly like one used by Bert Lahr, the distinguislied

Iegislation designed to prevent a repetition. See $\S 509$ of the Communications Act, addedi by 74 Stat. 897 (1960), 47 U.S.C. $\$ 509$ (Supp. V, 1964). The whole experience has had. interesting side effects also. For exanple, the FCC recently refused to renew a broadcast license partly because of involvement of two of the licensee's principals in the quiz shows several years before. In re Application of Melody Music, Inc., 36 F.C.C. 201 (1964).

7 See, e.g., Pavesich v. New England Life Ins. Co., 122 Ga. 190, 50 S.E. 68 (1904); Warren \& Brandeis, The Right to Privacy, 4 Hanv. L. REv. 193 (1890); Prosser, Privacy, 48 CALIF. L. REv. 383 (1960).

8 E.g., Fleisher v. WPIX, Inc., 30 Misc. 2d 17, 213 N.Y.S.2d 632 (Sup. Ct. 1961); cf. Nappier v. Jefferson Standard Life Ins. Co., 322 F.2d 502 (4th Cir. 1963).

${ }^{9}$ E.g., Maritote v. Desilu Productions, Inc., 230 F. Supp. 721 (N.D. Ill. 1964) (unsuccessful action by administratrix of estate of $\mathrm{Al}$ Capone, and by his wife and son, for appropriation of property right of decedent and invasion of privacy by telecasts ["TheUntouchables"] about Capone and his activities); Strickler v. NBC, 167 F. Supp. 68 (S.D. Cal. 1958); Bernstein v. NBC, 129 F. Supp. 817 (D.D.C. 1955), aff'd, 232 F.2d 369 (D.C. Cir. 1956); Smith v. Doss, 251 Ala. 250, 37 So. 2d 118 (1948); Leavy v. Cooney, 214 Cal. App. 2d 496, 29 Cal. Rptr. 580 (1963); Smith v. NBC, 138 Cal. App. 2d 807, 292 P.2d 600 (1956); Jacova v. Southern Radio \& Television Co., 83 So. 2d 34 (Fla. 1955); Smith v. WGN, Inc., 47 II. App. 2d 183, 197 N.E.2d 482 (1964); Youssoupoff v. CBS, 41 Misc. 2d 42, 244 N.Y.S.2d 701 (Sup. Ct.), aff'd per curiam, 19 App. Div. 2d 865, 244 N.Y.S.2d 1 (1963); Durgon v. CBS, 29 Misc. 2d 394, 214 N.Y.S.2d 752 (Sup. Ct. 1961).

10 Nappier v. Jefferson Standard Life Ins. Co., 322 F.2d 502 (4th Cir. 1963). For a recent survey of the developing hitigation in this field, see generally, FREEDOM OF INFORMAAtion Center, Publication No. 133, Turbulence in the Privacy Fieid 3-5 (1965).

11 Durgom v. CBS, 29 Misc. 2d 394, 214 N.Y.S.2d 752 (Sup. Ct. 1961); cf. Raynor v. ABC, 222 F. Supp. 795 (E.D. Pa. 1963), in which the court considered but decided on the. merits against granting an injunction against a scheduled dramatic broadcast.

12 Lahr v. Adell Chem. Co., 300 F.2d 256 (1st Cir. 1962). 
actor and comedian, that many listeners apparently assumed the voice of the duck was Lahr's. This, he alleged in his complaint against Adell, misappropriated his "creative talent, voice, vocal sounds and vocal comic delivery" and thus cheapened his professional standing by suggesting that he had stooped, or fallen, to the level of making ordinary commercials. Lahr sought recovery on three legal theories: defamation, invasion of privacy (or the corollary right of publicity), and unfair competition. Because of the complexity of the substantive law and the wide circulation of the commercials, the case might have raised serious conflict of laws problems, but the parties agreed to resolve their disputes under the laws of New York and Massachusetts. The district court found no merit in any of the claims, and dismissed the suit. ${ }^{13}$ The court of appeals reversed unanimously. ${ }^{14}$ Although unimpressed with the privacy claim, and uncertain about the allegations of unfair competition insufficiently stated in the complaint, the court concluded that there was a plausible claim of defamation. ${ }^{15}$ Actors had recovered in the past for insinuations that they were performing below their class, ${ }^{16}$ and for the moment that was enough to send the case back for trial.

The remand of the Lahr case left many questions unsettled. But in its approach to the defamation clain the court of appeals was more creative than the British Court of Appeal had been three years earlier. The British case involved strikingly similar facts. The H. J. Heinz Company had prepared a series of TV commercials for its products, featuring the antics of a cartoon character whose voice sounded enticingly like that of the actor Alastair Sim. Actually the voice was not Sim's at all but was that of an actor who had often mimicked Sim in the past. Upon learning of the commercials, Sim protested to the sponsor and, receiving no satisfaction, went to court for an injunction and damages. The Court of Appeal held only that there was no ground for a preliminary injunc-

${ }^{13} \mathrm{Lahr}$ v. Adell Chem. Co., 195 F. Supp. 702 (D. Mass. 1961). The district court characterized the plaintiff's theory of recovery as a "label-less, anonymous tort" which did not even deserve serious consideration. $I d$. at 704 .

14300 F.2d 256 (1st Cir. 1962).

16 By remanding the case on the defamation ground, the court avoided the immediate necessity to rule upon the unfair competition claim. In dictum, however, the court suggested that the plaintiff had alleged a colorable case of passing off, since "it could well be found that defendant's conduct saturated plaintiff's audience to the point of curtailing his market." Even though no claim of copyright protection could be demonstrated, the state law of unfair competition might nevertheless protect "a peculiar style and type of performance" of an entertainer. Id. at 259. For further consideration of these questions, and of the possible impact of recent Supreme Court decisions, see text accompanying notes 24673 infra.

${ }^{16}$ See, e.g., Louka v. Park Entertainments, Inc., 294 Mass. 268, 1 N.E.2d 41 (1936); cf. Gardella v. Log Cabin Prods., Inc., 89 F.2d 891 (2d Cir. 1937). 
tion. ${ }^{17}$ The opinion hinted, however, a view of the defamation claim less generous to the plaintiff than that of the Lahr court. On the other hand the British court was apparently more impressed than were the American judges by the charge of unfair competition.

Enough has now been said to indicate that tortious activity on television has becoine increasingly complicated. ${ }^{18}$ The simpler and more familiar defaination suits have been joined by newer claims involving invasion of privacy and unfair competition. This brief survey of recent hitigation compels an inquiry into the origins of the broadcaster's tort hability. That inquiry spans a period of almost forty years and covers myriad cases in the United States and abroad.

\section{LEGAL BASIS OF THE BROADCASTER'S TORT LIABIIITY}

The development of the broadcaster's liability for defamation and related torts has taken place in three stages. During the first period, the 1930's, the law was strict and the broadcaster's liability all but absolute. The end of the thirties saw a relaxation of these rigorous standards. In the next decade both courts and legislatures spoke inore in terms of "due care" than of "strict liability." Finally, with the advent of television in the 1950's there has come a third phase, a partial revival of the strict liability principle, but tempered by important exceptions and qualifications.

Although there was at least one unreported British case long before

17 Sim v. H. J. Heinz Co., [1959] 1 All. E.R. 547 (C.A.). For a discussion of this case, and analysis of the underlying issues, see Comment, 39 CAN. B. Rev. 409 (1961).

18 For a representative selection of recent cases involving defamation by radio and television, see, e.g., Riss v. Anderson, 304 F.2d 188 (8th Cir. 1962); Wanamaker v. Lewis, 173 F. Supp. 126 (D.D.C. 1959); Gearhart v. WSAZ, Inc., 150 F. Supp. 98 (E.D. Ky. 1957), aff'd, 254 F.2d 242 (6th Cir. 1958); Sargent v. NBC, 136 F. Supp. 560 (N.D. Cal. 1955); Correia v. Santos, 191 Cal. App. 2d 844, 13 Cal. Rptr. 132 (1961); Charles Parker Co. v. Silver City Crystal Co., 142 Conn. 605, 116 A.2d 440 (1955); American BroadcastingParamount Theatres, Inc. v. Simpson, 106 Ga. App. 230, 126 S.E.2d 873 (1962); Kennedy v. Mid-Continent Telecasting Co., 193 Kan. 544, 394 P.2d 400 (1964); Deshotel v. Thistlethwaite, $240 \mathrm{La} .12$, 121 So. 2d 222 (1960); Fontenot v. Fontenot, $235 \mathrm{La} .488$, 104 So. 2d 431 (1958); Niehoff v. Congress Square Hotel Co., 149 Me. 412, 103 A.2d 219 (1954); Young v. New Mexico Broadcasting Co., 60 N.M. 475, 292 P.2d 776 (1956); James v. Powell, 20 App. Div. 2d 689, 246 N.Y.S.2d 998, aff'd mem., 14 N.Y.2d 881, 200 N.E.2d 772, 252 N.Y.S.2d 87 (1964), cert. denied, 379 U.S. 966 (1965) ; Harwood Pharmacal Co. v. NBC, 17 Misc. 2d 208, 186 N.Y.S.2d 750 (Sup. Ct. 1959), af'd mem., 10 App. Div. 2d 607, 197 N.Y.S.2d 413 (1960), aff'd, 9 N.Y.2d 460, 174 N.E.2d 602, 214 N.Y.S.2d 725 (1961); Greer v. Skyway Broadcasting Co., 256 N.C. 382, 124 S.E.2d 98 (1962); Holden v. Pioneer Broadcasting Co., 228 Ore. 405, 365 P.2d 845 (1961); Purcell v. Westinghouse Broadcasting Co., 411 Pa. 167, 191 A.2d 662 (1963); Seegars v. WIS-TV, 236 S.C. 355, 114 S.E.2d 502 (1960); Gibler v. Houston Post Co., 310 S.W.2d 377 (Tex. Civ. App. 1958). 
$1930,{ }^{19}$ the history of the broadcaster's liability in the English speaking countries really dates from 1932. In that year two seminal cases were decided, one in Nebraska ${ }^{20}$ and the other in Victoria, Australia. ${ }^{21}$

Although the facts were similar, the two courts took radically different views of the legal issues. The American court, conscious that it was writing new law upon a clean slate, first determined that the defamatory words, though spoken rather than written, constituted "libel" rather than "slander." In addition, the broadcaster was considered hable regardless of fault because he occupied the position of a publisher rather than that of a distributor of the defamation. The Australian court, by contrast, held that spoken defamation, whether over the air or by an unaided voice, was still slander. The consequences of this distinction were of course critical: Libel was usually actionable without proof of special damages, while only certain narrow categories of slander would support a claim for general damages. ${ }^{22}$ Thus the success of the plaintiff's case would often depend upon whether the defamation was classed as libel or slander.

For the next few years, the American courts generally followed the Nebraska decision classifying radio defamation as libel and holding the broadcaster strictly accountable as a "publisher."23 These criteria produced harsh results where, for example, the defamatory broadcast originated at the network studio and was carried locally by a small station that had no chance to check it before it went over the air. ${ }^{24}$ The rule was also inequitable in the case of certain political broadcasts which the "equal-time" provision of the Communications Act ${ }^{25}$ (or its predecessor in the Radio Act of $1927^{26}$ ) compelled the broadcaster to carry. ${ }^{27} \mathrm{Un}$ derstandably, then, there was much discussion of the wisdom of these principles of law, but they were seldom relaxed by the courts during the early days of commercial radio.

The inequity and unworkability of the Nebraska rule were not fully apparent until the courts were required to deal with the problem of de-

19 Williams \& Norgate, Ltd. v. BBC, noted in 70 Sor. J. 613 (1926), styled by the commentator "the first slander case to have arisen out of the broadcasting of defamatory matter ...." The brief notation of the case contains no reference to the court's conclusion or any other matters concerning the case. See also 99 CenrT. L.J. 204 (1926).

20 Sorensen v. Wood, 123 Neb. 348, 243 N.W. 82 (1932).

21 Meldrum v. Australian Broadcasting Co., [1932] Vict. L.R. 425, [1932] Aust. L.R. 452.

22 See generally Prosser, Torts 769-83 (3d ed. 1964).

23 See, e.g., Miles v. Louis Wasmer, Inc., 172 Wash. 466, 20 P.2d 847 (1933).

24 See, e.g., Coffey v. Midland Broadcasting Co., 8 F. Supp. 889 (W.D. Mo. 1934).

25 § 315, 48 Stat. 1088 (1934), as amended, 47 U.S.C. \& 315 (Supp. V, 1964).

26 Federal Radio Act, § 18, 44 Stat. 1170 (1927).

27 Compare Sorensen v. Wood, 123 Neb. 348, 243 N.W. 82 (1932), will Josephson v. Knickerbocker Broadcasting Co., 179 Misc. 787, 38 N.Y.S.2d 985 (Sup. Ct. 1942). 
famatory interpolations. In the first major "ad lib" case, the Pennsylvania Supreme Court in 1939 broke with tradition and absolved the broadcaster because there had been no showing of failure to exercise due care. ${ }^{28}$ Absolute liability, declared this court, was both unnecessary and dangerous. Its application here miglit not only jeopardize federal regulation of the industry but miglit unwisely stifle free discussion. ${ }^{29}$ In addition, the absolute liability standard was inequitable, and seemingly incompatible with the general developinent of tort law. ${ }^{30}$

During the 1940's and early 1950's two trends appeared: The courts increasingly adopted the Pennsylvama rule of liability only for negligence, whether they classified radio defamation as libel or slander; and state legislatures were active in the adoption of statutes freeing the broadcaster of all hability under certain conditions and recognizing the due care standard in other situations. ${ }^{31} \mathrm{~A}$ few of these state laws immunized the affiliated local station for defamatory broadcasts originating at the network's key stations. Several statutes distinguished between defamation spoken by a nember of the station's staff, for which the broadcaster remained absolutely liable, and by one not in the broadcaster's employ. ${ }^{32}$ Several of these state laws prescribed the type of damages that could be awarded, for example restricting the plaintiff to recovery of "actual damages."

The last and current stage of this legal development lias coincided with the age of commercial television. Most of the recent cases involve TV

28 Summit Hotel Co. v. NBC, 336 Pa. 182, 8 A.2d 302 (1939). It should be noted that the Pennsylvania courts would not, apparently, have held even a newspaper or magazine publisher absolutely liable for the dissemination of such defanatory material. Thus the decision may have been less of a break with tradition than the result might at first suggest. See Note, 88 U. PA. I. REv, 122, 124 (1939).

29 See $336 \mathrm{~Pa}$. at $200-03,8 \mathrm{~A} .2 \mathrm{~d}$ at $310-11$.

$30 \mathrm{Id}$. at $202,8 \mathrm{~A} .2 \mathrm{~d}$ at 311 . The court may also have been influenced by the reluctance of the American Law Institute's recently issued Restatement of Torts to take any position on this question. The Institute's caveat refusing to resolve the issue either way was, the court observed, adopted "after full discussion, on the ground that the decided radio cases were insufficient in number to require the acceptance of an analogy presenting such serious practical and legal difficulties." Id. at 195, 8 A.2d at 308. See Restatement, TorTs $\S 577$, comment $g$ (1934).

31 For discussion and examples of early state legislation conferring partial privileges or immunities upon the broadcaster, see generally Remmers, Recent Legislative Trends in Defamation by Radio, 64 HARv. L. REv. 727, 739-46 (1951); Sprague, More Freedom of the Air, 11 AIR L. REv. 17, 25-28 (1940); 1 J. Radro Law 572, 576-78 (1931). The American Civil Liberties Union, among others, proposed in the 1930's an exemption for broadcasters fron liability based upon naterial which the federal equal-tine law conpelled them to carry. See Sprague, Freedon of the Air, 8 AIR L. Rev. 30, 44 (1937).

32 See generally Remmers, supra note 31 , at $740-42$; for examples of the many variations of this general formula of absolution, see statutes cited note 81 infra.

83 See Renuniers, supra note 31 , at 745. 
programs, for radio is infrequently a source of major tort litigation. Also, the cases no longer involve exclusively defamation, as the examples already cited may suggest. Invasion of privacy has become more important during the last decade, and defamation less.

\section{A. The Legal Issues, Old and New}

This field of law, then, is rich and becoming progressively richer. The wonder is that so little has been written about it of late. During the 1930's and early forties the situation was precisely the reverse of what it has been in the fifties and sixties. For every decided case there were a dozen articles, notes and comments. ${ }^{34}$ As the pace of litigation quickened, however, the stream of scholarly comment practically ceased. What was once a torrent of discussion and analysis in the legal journals is now only a trickle. ${ }^{35}$ This curious inverse ratio of cases to comment requires explanation.

Perhaps the best key to the paradox is that those who wrote in the early days of radio exhausted themselves on the wrong issues. Their gaze was fixed on two questions that were not central and have become progressively even less relevant: The distinction between libel and slander (which category included radio defamation?); and the difference between the

34 It would be futile to attempt a comprehensive list of the materials from the early period. A representative selection, however, might include Davis, Libel and Slander by Radio, 34 CASE \& Conarent 67 (1928); Fannum, Radio Defamation and the American Law Institute, 16 B.U.L. Rev. 1 (1936); Finlay, Defamation by Radio, 19 CAN. B. Rev. 353 (1941); Haley, The Law on Radio Programs, 5 GEO. WASH. L. REv. 157, 171-97 (1937); Redmond, Reading from Script into Broadcasting Apparatus-Libel or Slander, 7 AUSTL. L.J. 257 (1933); Royce, Defamation via Radio, 1 Omo ST. L.J. 180 (1935); Seitz, Responsibility of Radio Stations for Extemporaneous Defamation, 24 MARQ. L. REv. 117 (1940); Vold, The Basis for Liability for Defamation by Radio, 19 MINN. L. REv. 611 (1935); Vold, Defamation by Radio, 2 J. RADIo LaW 673 (1932); Vold, Defamatory Interpolations in Radio Broadcasts, 88 U. PA. L. REv. 249 (1940); and many dozen notes, comments, and casenotes on the principal cases decided during these early years.

35 Among the rather small number of recent articles, all dealing with television as well as radio defamation and related torts, are Barry, Radio, Television and the Law of Dafanation, 23 Austr. L.J. 203 (1949); Harum, Choice of Law in Broadcast Defamation, 38 FrA. B.J. 266 (1964); Harum, Federal Occupation of Political Defamation, 49 A.B.A.J. 1096 (1963); Harum, Remolding of Common Law Defamation, 49 A.B.A.J. 149 (1963); Korhel, Defamation by Broadcast: The Need for Federal Control, 49 A.B.A.J. 771 (1963); Leflar, Radio and TV Defamation: "Fault" or Strict Liability?, 15 O\#̈о ST. L.J. 252 (1954); Reid, Broadcast Defamation, 30 SOUTHERN SPEECH J. 199 (1965); Warner, Multistate Publication in Radio and Television, 23 LAW \& Conteasp. Prob. 14 (1958). One recent case, American Broadcasting-Paramount Theatres, Inc. v. Simpson, 106 Ga. App. 230, 126 S.E.2d 873 (1962), elicited a considerable response from the journals in the form of casenotes. See, e.g., 12 AM. U.L. REv. 222 (1963); 25 GA. B.J. 310 (1963); 1 Houston L. REv. 58 (1963) ; 46 MARQ. L. REV. 397 (1962-63); 36 TEMP. L.Q. 240 (1963); 37 TvL. L. REv. 147 (1962); 16 VAND. L. REv. 472 (1963) ; 9 WAYNE L. REv. 391 (1963). Few of the other recent decisions seem, however, to have provoked more than a sporadic casenote or footnote in a comment or note dealing with a related issue. 
liability of a publisher and that of a distributor (which of these was the radio broadcaster?). The preoccupation with these questions, based on the hasty assumption that they were the relevant questions, may have been largely responsible both for the withdrawal of the commentators from this field at a time when their guidance has been most needed, and for the inapplicability of much of the early learming to the difficult new problems of television. In fairness, then, we ought to explore these two pervasive questions.

\section{The Libel-Slander Distinction}

The law of defamation assumed its present character in a day when broadcasting and even sound amplification were unknown. ${ }^{36}$ The legally significant distinction between libel and slander has always rested on history rather than logic. Over the years it has withstood reasoned attacks by worthy critics. ${ }^{37}$ Seldom has the distinction been completely abolished except by legislative fiat, and even that has been rarely done. ${ }^{38}$ Yet through it all, most scholars have insisted that the distinction makes little sense even in the simplest cases. ${ }^{39}$

Whatever may be said generally for the hibel-slander dichotomy, it is peculiarly inapplicable to radio and television..$^{40}$ Specifically, the results of a literal application of this distinction to broadcasting are often not those which a rational and just legal system should produce. It always

${ }^{36}$ See generally Holdsworth, Defamation in the Sixteenth and Seventeenth Centuries, 41 L.Q. REv. 13 (1925); Lovell, The "Reception" of Defamation by the Common Law, 15 VAND. L. REv. 1051 (1962); Veeder, The History and Theory of the Law of Defamation, 4 Corus. L. Rev. 33 (1904).

37 One of the earliest, and most forceful, critics, was Lord Mansfield, in Thorley v. Lord Kerry, 4 Taunt. 355, 128 Eng. Rep. 367 (1812).

${ }^{38}$ Apparently no American states have taken so bold a step by statute, although one or two have done so by judicial decision. Statutes assimilating bibel and slander have, however, been adopted by several Australian states and Canadian provinces. See Frmang, TORTS 488 \& nn.37-39 (2d ed. 1961). In England, despite the recommendation of a select Committee of the House of Lords in 1843, this step has never yet been taken. The hbelslander distinction was partially eradicated by the Defamation Act of 1952, but not wholly.

See Statutes, 16 Mov. L. REv. 198, 201 (1953).

39 Dean Prosser's pungent criticism is representative: "Nothing but historical survival of the relics of forgotten jurisdictional conflicts accounts for a state of affairs peculiar to the common law, and unknown elsewhere in the civilized world. Nowhere is the layman's criticism and the cry, 'kill all the lawyers first,' more thoroughly justified. Undoubtedly the ingenuity of the judge and good sense of the jury often will introduce some degree of flexibility, but more often they are quite helpless before rigid and arbitrary categories." Prosser, TORTs 783 (3d ed. 1964). See also, e.g., Courtney, Absurdities of the Law of Slander and Libel, 36 Arr. L. Rev. 552 (1902); Donnelly, The Law of Defamation: Proposals for Reform, 33 Mins. L. Rev. 609 (1949).

40 See, e.g., Leflar, Radio and TV Defamation: "Fault" or Strict Liability?, 15 Omo ST. L.J. 252, 253 (1954); Comment, 1957 WaSH. U.L.Q. 282, 289; Note, Basis of Liability in Radio Defamation, 29 B.U.L. Rev. 245, 247 (1949). 
seemed monstrous, for example, to deny recovery to one who has been falsely called a Communist over the air because he was able to show neither "special damages" nor actual disparagement of his professional qualifications. Yet that was precisely the consequence of a rigid, instinctive application of the law, for defamation by radio was "spoken" rather than "written." 41 To relax the categories in order to reach an obviously more just result would, of course, flout four centuries of history. The legal meaning of the difference between "writing" and "speaking" had deep roots.

Even the more creative courts could reach a sounder conclusion in such cases only by forcing radio defamation into the "libel" category. ${ }^{42}$ This was done by marshalling several more or less strained analogies. There was, for example, a thin but respectable line of English cases holding that the reading of a defamatory letter was libel rather than slander. ${ }^{43}$ These cases did not, however, really answer the problem for at least three reasons: First, because their foundation, never firm, had been sharply questioned by a high British court; ${ }^{44}$ second, because the central distinction in these cases rested on the logically irrelevant factor of whether the defamation was read from a script; ${ }^{45}$ and finally because the very significance of having read the defamation from a letter-that reading apprised the listener that the defamation had a more permanent form-was meaningless when, as on the air, the listener could not see the speaker. ${ }^{40}$ This analogy, then, was weak justification for reaching an obviously preferable result.

There were other ways of making the libel-slander distinction turn on permanence of form rather than on the written-spoken issue. Some courts drew by analogy upon cases classifying motion picture sound tracks as libel. ${ }^{47}$ But these cases were little more helpful than the letter-reading cases since they really applied only when the program was recorded before or during presentation. To be sure, recording made it possible to re-

41 See Developments in the Law-Defamation, 69 HARv. L. REv. 875, 888-89 (1956). 42 See, e.g., Hartmann v. Winchell, 296 N.Y. 296, 73 N.E.2d 30 (1947); cf. Charles Parker Co. v. Silver City Crystal Co., 142 Conn. 605, 116 A.2d 440 (1955).

43 Forrester v. Tyrrell, 9 Times L.R. 257 (1893); John Lamb's Case, 9 Co. Rep. 59b (1610); De Libellis Famosis, 5 Co. Rep. 125a (1605).

44 Osborn v. Thomas Boulter \& Son, [1930] 2 K.B. 226, 231 (C.A.).

45 See Hartmann v. Winchell, 296 N.Y. 296, 300-03, 73 N.E.2d 30, 32-33 (1947) (Fuld, J., concurring).

46 See American Broadcasting-Paramount Theatres, Inc. v. Simpson, 106 Ga. App. 230, 236, 126 S.E.2d 873, 877 (1962).

47 E.g., Landau v. CBS, 205 Misc. 357, 128 N.Y.S.2d 254 (Sup. Ct. 1954). But of. Remington v. Bentley, 88 F. Supp. 166, 169 (S.D.N.Y. 1949), an early television case in which the sound movie analogy was rejected. For the sound movie doctrine, see Brown v. Paramount Publix Corp., 240 App. Div. 520, 270 N.Y. Supp. 544 (1934). 
peat the defamation, a fact critical in classifying the movie sound tracks. Where the recording was made for the network's or the station's own files, however, and never replayed on the air, that factor should not have influenced a choice which traditionally rested on the greater damage which defamatory inaterial might do in permanent form. ${ }^{48}$

Other courts classified the defamatory broadcast as libel because it involved the kind of "deliberation" that was characteristic of libellous writings. ${ }^{49}$ Deliberation there undoubtedly was in the case of the defamatory script, but this was irrelevant to the inuch harder case of the defannatory ad hib. Here there could hardly be said to have been any deliberation, either on the part of the speaker or of the broadcaster (who usually claimed to be at least as surprised as the plaintiff). Yet the defamatory ad lib was quite as capable of doing serious injury to reputation as was a libellous script.

A few courts and commentators invoked a principle which resolved the issue, but without reasons: Traditionally, novel forms of injury to reputation had been treated as hbel rather than as slander. ${ }^{50}$ The only reason given for this trend was a feeling that the scope of slander should be narrowed wherever possible because of its inequities, inconsistencies, and difficulties of proof. The trouble was, however, that radio defannation was not really novel in kind. (and was therefore unlike the other cases to which the "novelty" principle had been applied) ${ }^{51}$ but only in degree. Thus even this arbitrary basis of distinction did not satisfactorily resolve the issue.

Gradually attention focussed on more relevant attributes of radio defamation, which raised questions of policy rather than purely of precedent. The difference between the speech to a small group and the address to a radio audience of millions was admittedly only one of degree. That difference, however, was so vast that principles developed in the days of drawing-rooin inuendoes simply no longer applied. This did not mean that the defamatory broadcast was precisely like anything that had pre-

48 See Note, 71 Harv. L. REv. 384 (1957).

49 See Note, Damages for Defamation by Radio, 25 CHI.-KENT L. REv. 142, 147 (1947); Vold, Defamation by Radio, 2 J. Radio LAw 673, 690-92 (1932); 3 AIR L. REv. 64, 67 (1932).

50 See Haley, The Law on Radio Programs, 5 Geo. WaSH. L. Rev. 157, 184-85 (1937); 81 U. PA. L. REv. 228, 229 (1932).

51 The law of libel has, for example, been extended to include such unlikely injuries to reputation as those involved in statues, Monson v. Tussauds, [1894] 1 Q.B. 671; hanging the plaintiff in effigy, Eyre v. Garlick, 42 J.P. 68 (1878); dishonoring a check validly drawn on the defendant's bank, Svendsen v. State Bank of Duluth, 64 Minn. 40, 65 N.W. 1086 (1896); and "shadowing" or following the plaintiff in an obvious and embarrassing fashion, Schultz v. Frankfort Marine, Accident \& Plate Glass Ins. Co., 151 Wis. 537, 139 N.W. 386 (1913). 
viously been regarded as libel, but rather reflected a frank recognition that the attempt to find the closest factual analogy had largely missed the point. Eventually, the legal issue was resolved, or in some cases avoided, on grounds of public policy, but this came about after years of tilting at a legal windmill that would not budge.

\section{Standard of the Broadcaster's Liability}

The other question that preoccupied the experts during the early years was that of the broadcaster's liability: Should he be liable regardless of fault, or only for the absence of due care? If he were considered to be a "publisher," then strict liability would be appropriate, as for other publishers. ${ }^{52}$ If, on the other hand, he were only a disseminator, with the speaker regarded as the publisher, a due care standard would be more suitable. ${ }^{53}$ The issue was debated endlessly in the literature without satisfactory resolution in the courts. $^{54}$ Again the debate revolved largely about a set of analogies that did not quite fit. Meanwhile the more pertinent policy issues were slighted.

Broadcasters sought exemption from the publisher's liability by contending, for example, that they should be given a privilege or immunity like that long enjoyed by telegraph companies. ${ }^{55}$ There were, however, some rather obvious differences between the two media: First, the telegraph company was under a common carrier's duty to transmit almost anything that came across the counter $;^{56}$ second, the transmission process was virtually automatic, affording little opportunity for inspection of each message; ${ }^{57}$ third, to require such inspection would seriously inhibit a communication inedium to which speed, accuracy, and some degree of confidentiality are obviously vital. Moreover, the cryptic language frequently used in telegraphy presumably made it difficult to detect all but the most obviously defamatory inaterial. Thus the telegraplier has never been expected to catch and withhold from the wires the few fragments

52 See, e.g., Corrigan v. Bobbs-Merrill Co., 228 N.Y. 58, 126 N.E. 260 (1920).

53 Various persons who play only a secondary part in the dissemination of defamation that has been published by another are held hable only for lack of due care. Such persons include news vendors, Balabanoff v. Fossani, 192 Misc. 615, 81 N.Y.S.2d 732 (Sup. Ct. 1948); distributors of periodicals, Sexton v. American News Co., 133 F. Supp. 591 (N.D. Fla. 1955); and hbraries, Vizetelly v. Mudie's Select Library, [1900] 2 Q.B. 170.

54 See the discussion of the analogy, and the materials cited in Summit Hotel Co. v. NBC, 336 Pa. 182, 192-95, 8 A.2d 302, 307-08 \& nn.13, 14 (1939).

55 See Davis, Radio Comaronication 116-69 (1928) for the statement of the argument in favor of the analogy. The telegrapher's hability is fully discussed in Smith, Liability of a Telegraph Company for Transmilting a Defamatory Message, 20 CoLum. L. REv. 30, 369 (1920); and cases are collected in Annot., 63 A.L.R. 1118 (1929).

56 See Vold, The Basis for Liability for Defamation by Radio, 19 MnNN. L. REv. 611, 653 (1935).

57 See Finlay, Defamation by Radio, 19 CaN. B. Rev. 353, 366-67 (1941). 
of defamation that may be among the millions of messages he daily transmits.

A proferred analogy to the telephone companies was similarly dismissed. ${ }^{58}$ The telephone operator retained, if anything, somewhat less control over the individual message than the telegrapher, and detection of defamation here would require an even deeper intrusion into the privacy of personal communications. Finally, there has been hittle support for the analogy between the broadcaster and the lessor of an auditorium in which or public address system over which a defamatory speech is given. ${ }^{59}$ The responsibility of such a person for the dissemination of the injurious message was obviously quite different from that of the radio broadcaster.

The rejection of these analogies eventually narrowed the choice to two lines of cases-those involving book, newspaper, and magazine publishers (whose hability was absolute) and those holding newsdealers, booksellers, and other distributors only to a standard of due care. On the one hand it was argued that the broadcaster and the pubhsher were usually competitors for audience attention and advertising revenue, and engaged im somewhat similar functions, so they should incur similar liability for injuries to reputation. ${ }^{60}$ Publisher and broadcaster alike furnished and controlled the facilities which magnified the defamatory statement a thousandor million-fold and gave it an instantaneous wide circulation which greatly magnified the potential for harm. Finally, both could largely shift the risk of loss through imsurance or indemnification. ${ }^{61}$

These argnnients were widely accepted in the case of defamation broadcast from a script which lrad been subinitted to the broadcaster for examination. But in the cases of the script that could not be inspected, or the simultaneous network broadcast, or the defamatory ad lib, the broadcaster should no more be held strictly accountable, it was argued, than should the newsdealer be liable for any defamatory charge on the inside pages of the morning journal..$^{62}$ Of course the broadcaster could and often did instruct his engineers or control room personnel to monitor all broadcasts and cut the speaker off the air if any defamation appeared. But the difficulty with this device was twofold. On the one hand even the trained libel lawyer could not always judge the defamatory

58 See Note, Television Defamation-Libel or Slander?, 42 VA. L. REv. 63, 68-69 (1956).

59 The analogy was suggested by Bohlen, Fifty Years of Torts, 50 FARv. L. REv. 725, 731 (1937). For a reaction to this analogy, see Comment, Libel and Slander-Classification of Radio Defamation-Liability of Broadcaster, 39 MicH. L. REv. 1002, 1007 (1941).

${ }^{60}$ See Sorensen v. Wood, 123 Neb. 348, 357, 243 N.W. 82, 86 (1932).

61 See Donnelly, Defamation by Radio: A Reconsideration, 34 IowA L. REv. 12, 25 (1948).

62 See Comment, Defamation by Radio, 4 J.B.A. Kan. 245, 247 (1936). 
character of a statement on the spur of the moment, particularly where the words themselves gave no clue to the injury they conveyed; so much the less could one expect a radio engineer to make accurate spot judgments. ${ }^{63}$ On the other hand many cases involved only a defamatory sentence or two, which was over the air before even the expert lawyer could react. ${ }^{64}$ So in these cases-the simultaneous network broadcast and the defamatory ad lib-the proponents of absolute liability virtually had to concede that their position rested on grounds of policy similar to those that had long governed extra-hazardous activities. ${ }^{65}$ There was something artificial about framing this policy question in terms of the broadcaster's similarity to the publisher or the bookseller. The debate was unsatisfactory because neither analogy fit all the cases. Yet this kind of debate was a virtually inevitable result of the attempt to press a new medium of communication into an ancient, already archaic, legal framework.

The time and energy devoted to these two questions were, as we have seen, hardly commensurate with the return. Worse, perhaps, was the resulting withdrawal of attention from the issues that ought to have been debated and resolved during these years. A quick survey of the most egregiously neglected questions may corroborate this charge.

Surely there was no aspect of the radio broadcaster's liability more deserving of special treatment than the impact of the conflict of laws. It was apparent almost from the beginning that courts would find it necessary to struggle with sucli questions. The Supreme Court early observed that "no state limes divide the radio waves." media had long been plagued by state-to-state variations in defamation law, ${ }^{67}$ particularly in the treacherous days before recognition of the singlepublication principle. The broadcaster faced perils equal to those of the publisher or worse in at least two respects: Not only was the reach of the radio wave far less predictable and controllable than that of the book or magazine, but there was the unique problem of the network broadcast heard simultaneously through local outlets in many states,

${ }^{63}$ See Guider, Liability for Defamation in Political Broadcasts, 2 J. Radio Law 708, 712 (1932).

64 See Graham, Defamation and Radio, 12 Wask. L. Rev. 282, 289 (1937).

65 For a scholarly debate on the appropriateness of this theory of strict liability, compare Seitz, Responsibility of Radio Stations for Extemporaneonls Defamation, 24 MarQ. L. Rev. 117, 123-25 (1940), with Vold, Extemporaneous Defantation by Radio: A Rejoinder, 25 Marq. L. Rev. 57, 61-65 (1941). (1933).

66 Federal Radio Comm'n v. Nelson Bros. Bond \& Mortgage Co., 289 U.S. 266, 279

67 See, e.g., O'Reilly v. Curtis Pub. Co., 31 F. Supp. 364 (D. Mass. 1940); Leflar, The Single Publication Rule, 25 Rocky Mr. L. Rev. 263 (1953); Prosser, Interstate Publication, 51 Mich. L. Rev. 959 (1953). 
which found no real counterpart anywhere in the publishing trade. Even if the law governing the publisher's interstate liability had been fairly uniform in the early thirties-which it clearly was not-the broadcaster's plight deserved sonie special consideration. Such consideration has been late in coming, although the subject has now been fully explored elsewhere. ${ }^{68}$

The special problems of network broadcasting were hardly confined to the conflict of laws. As the first network case made clear, there would be need for careful consideration and accommodation of the habilities of the network, the "key station" originating the offending program, and the station which carried it. ${ }^{69}$ There was an early atteinpt, for example, to analogize the local station to the newspaper carrying an actionable dispatch from the news service wires. Apart from the obvious differences between the two cases, the results flowing from this analogy were often at variance with the results dictated by other relevant analogies. For instance, if the originating station was a "publisher" of defamation as most courts found, then it was hard to avoid the conclusion that the local station was equally a "publisher." Thus the wire-service analogy sinply gave no satisfactory solution to the network cases.

During the early years only cursory attention was given to the various devices available for shifting liability. More than one court eased its conscience in finding the broadcaster absolutely liable by suggesting that insurance was always available as a backstop. ${ }^{70}$ The suggestion was made, of course, with virtually no information about the extent of insurance carried by the industry, or even about the availability of adequate coverage at reasonable rates. ${ }^{71}$ These oversights may have been significant

68 See, e.g., EHRENZwerg, Confuict of Laws \$ 216 (1962); Warner, Multistate Publication in Radio and Television, 23 LAW \& ContearP. Prob. 14 (1958); Developments in the Law-Defanation, 69 HARv. L. Rev. 875, 950-57 (1956) ; Comment, 56 Nw. U. L. Rev. 823 (1962); Comment, 10 LA. L. Rev. 339 (1950); Note, 11 OkLA. L. Rev. 61 (1958).

69 Coffey v. Midland Broadcasting Co., 8 F. Supp. 889 (W.D. Mo. 1934). This decision, which held the local station strictly liable for defamation received from the network's wires and rebroadcast locally, provoked much comment in the journals, most of it critical of the harshness of the result. See, e.g., 15 B.U.L. REv. 651 (1935); 6 AIR L. Rev. 81 (1935); 14 ORE. L. Rev. 492 (1935); 8 So. CaI. L. Rev. 359 (1935); 21 VA. L. Rev. 705 (1935).

70 Coffey v. Midland Broadcasting Co., sutpra note 69.

${ }^{71}$ For a discussion of the availability and types of insurance, see generally Donnelly, The Right of Reply: An Alternative to an Action for Libel, 34 VA. L. Rev. 867, 881 (1948); Friedenthal \& Medahe, The Impact of Federal Regulation on Political Broadcasting: Section 315 of the Communications Act, 72 HARv. L. REv. 445, 484 (1959); Leflar, Radio and TV Defamation: "Fault" or Strict Liability?, 15 O\#TO Sr. L.J. 252, 266 (1954); Developments in the Law-Defamation, 69 HARv. L. Rev. 875, 914-16 (1956). The vice president of one of the major networks has observed, "practically all broadcasters carry insurance policies which cover defamation and privacy litigation." Letter from Mortimer Weinbach, Vice President of American Broadcasting Co., to the Author, March 26, 1965.

The broadcaster can hardly claim he has not been apprised of the importance of carry- 
for one reason not present in the typical case where insurance becomes relevant: While there would be little doubt about the validity of insurance protection against liability predicated on negligence, there is at least a question how far insurance may serve to insulate the intentional wrongdoer. There were, of course, few suggestions that even in the case of defamation originating in the defendant's studio, the broadcaster was a deliberate tortfeasor; indeed, one of the very foundations for strict liability under the "publisher" analogy was a recognition that tortious intent would be hard to prove except in the most outrageous cases. ${ }^{72}$ In addition, if the person primarily bable (the speaker or actor, usually) is judgment-proof, and the insurer's liability accrues as soon as judgment is rendered, which seems usually to be the case, then the insurance coverage might be sustained simply as a protection of the injured plaintiff's riglit to compensation rather than as a license to the defendant. ${ }^{73}$ The questions raised by the application of insurance to broadcasting were not insoluble; the point is only that they should lave been dealt with more extensively once the courts became concerned about them.

Related to the insurance question was the problem posed by the multiplicity of possible defendants. No one doubted that the person who actually delivered the defamation over the air was hable, and absolutely so. The hard questions concerned the hability of the other participants in the enterprise, the producer, director, and even the engineer in the studio; the sponsor and the advertising agency which prepared at least the commercial copy and perhaps a good deal of the program content; the broadcaster, of course; and, it was even suggested at one point, even the owner of any receiving set which disseminated the offending material. ${ }^{74}$

It was occasionally proposed to avoid most of these questions through soine form of indemnification imposing ultimate liability on the party most

ing insurance. $A$ recent advertisement by a leading issuer of broadcast defamation insurance in a national trade magazine warns:

Here's the Answer to Libel Suits:

One slip of the lip, Lowever accidental, can bring about court action-with you as the defendant in a libel suit. It can be costly enough to be disastrous. Now you can hold your loss on any claim to an agreed amount you carry yoursclf, and let [the advertiser] ... handle the excess. This specially designed policy provides economical protection against losses due to libel, slander, invasion of privacy, piracy, violation of copyright. ... .

Broadcasting, April 19, 1965, p. 26.

72 This logical difficulty was avoided by some advocates of absolute liability by pointing out that the broadcaster was at lcast a knowing and deliberate participant in the physical acts leading up to the defamatory broadcast. See Vold, Defamatory Interpolations in Radio Broadcasts, 88 U. PA. L. Rev. 249, 274-76 (1940).

73 See Developments in the Law-Defamation, 69 HARv. L. Rev. 875, 916 (1956).

74 See Note, Radio Defamation-An Unexplored Field of Law, 14 N.Z.L.J. 266 (1938). 
clearly at fault. ${ }^{75}$ The proposal was undermined, however, in that the person whose irresponsible speech creates the injury is also quite likely to be financially irresponsible. ${ }^{76}$ Then, too, especially in the network situation, there would often be serious barriers to bringing the speaker before the courts of the plaintiff's state. Finally, indemnification raised some of the same policy questions that complicated the insurance issue, particularly where the broadcaster's liability was held to be absolute. These subtle questions, however, were seldom considered in the journals until after they had been several times before the courts.

Perliaps the inost serious oversight had to do with state legislation immunizing the broadcaster. As the problems of ad lib defamation and network broadcasting loomed more important, it became increasingly obvious that strict liability was not the answer. Thus, even before World War II, several states relaxed this standard, ${ }^{77}$ but it was developments at the federal level which touched off the major wave of state lawmaking in this area. In 1948 the FCC held unequivocally that the broadcaster had no power of censorship over political speeches he was required to carry by the "equal time" law. ${ }^{78}$ Althougli the Commission also suggested that the federal obligation imphed an immunity from state tort liability, that was a dictum with rather shaky underpinning. ${ }^{79}$ The industry understandably did not trust the Commission's blandishments, and turned to Congress for relief. During the next few years the Congress failed to act favorably on any of the numerous immunity proposals brought before it. ${ }^{80}$ The broadcasters now had a very strong case to take

75 See, e.g., Donnelly, supra note 61 , at 25 ; Vold, supra note 56 , at 636 . The suggestion concerning indemnification is still important. A major network representative recently reported, for example, that "insofar as alleviating the threat of such bitigation is concerned, CBS does, of course, endeavor to obtain from those supplying program elements to it full warranties and indemmities for the material so furnished." Letter from Ralph E. Goldberg, Law Department, Columbia Broadcasting System, Inc., to the Author, April 12, 1965. However, the National Association of Broadcasters' standard form contract for political broadcasts contains no indemnity clause. See National Ass's of Broadcasters, Poltticat BroadCAST CATEChISM 17 (4th ed., rev. 1964).

76 See Haley, supra note 50, at 196.

77 See Remmers, Recent Legislative Trends in Defamation by Radio, 64 HaRv. L. Rev. $727,739-41$ (1951).

78 Port Huron Broadcasting Co., 12 F.C.C. 1069 (1948).

79 The principal basis for the Commission's assurance on the immumity question was an earlier court decision that the Communications Act preempted all state tort claims against telegraph compamies, O'Brien v. Western Umion Tel. Co., 113 F.2d 539 (Ist Cir. 1940). The apphicability of that case to the broadcaster's problem was doubtful at best. Thus much uncertainty remained despite the Port Huron decision. See generally De Grazia, Equal Political Defamation for All: Section 315 of the Federal Communications Act, 20 GEO. WASE. L. Rev. 706 (1952); Comment, The Broadcaster's Liability Under Section 315 of the Communications Act, 4 BAXIOR L. Rev. 516 (1952).

${ }^{80}$ See, e.g., H.R. 6949, 81st Cong., 1st Sess. (1950); H.R. 5470, 82d Cong., 1st Sess. 
to the state legislatures, and the response was a rash of new state laws, some of which went substantially further than necessary to relieve the broadcasters of the equal-time dilemma. ${ }^{81}$ Thus by 1960 , when the Supreme Court decreed such a federal immunity for equal-time broadcasts, all but a handful of states had anticipated or exceeded the impact of that holding. ${ }^{82}$

There is, of course, no way of telling what might have happened in the states had the broadcasters not had things quite so much their own way. It seems fair, however, to speculate that had the scholars and critics not fought so hard and so long for the untenable line of hability without fault, and turned instead to drafting statutes to accommodate more realistically the interests of the injured party and the industry, the

(1952); S. 2539, 82d Cong., 2d Sess. (1952); H.R. 7062, 82d Cong., 2d Sess. (1952) ; H.R. 7756, 82d Cong., 2d Sess. (1952).

81 State legislatures liave dealt with the problem of political broadcasts in several ways. Variations are found in the scope of the immunity given: (1) In many instances, the broadcaster is liable under no circumstances for a defamatory utterance over his facilities by a candidate for public office, e.g., OKIA. STAT. ANN. tit. 12, § 1447.2 (1951); N.Y. CrvII RrGHIS LAW $\$ 75$. (2) Some states extend the scope of the immunity to utterances by or on behalf of a candidate, e.g., N.H. Rev. Stat. ANv. ch. 507-A:2 (Supp. 1963); Miss. Code ANN. § 1059.5(2) (1956). (3) Nebraska goes even furtler, seeming to extend the immunity to any defamatory statement against a candidate for public office regardless of whether made by or on behalf of a candidate, NEB. Rev. Stat. $\S 86-602$ (1958).

In many states various limitations are then put upon the immunity: (1) The broadcaster is liable for a defamation by, on behalf of, or against, as the case may be, a candidate if, under federal laws or the regulations of federal agencies, the broadcast could be censored or controlled, e.g., WIs. Stat. ANN. \$331.052 (1958); PA. Stat. ANn. § 12.1585 (1953); but of. Wyo. Stat. § 1-873 (1947); VA. Code AnN. \$ 8-632.1 (1948); e.g., where no reference is made to censorship or control (i.e., the immunity appears to be unlimited). (2) An altogether different type of limitation is found in two states where an announcement must be made either before and after broadcast, or after broadcast: S.C. CODE § 23-7 (1962) ("The broadcast you have just heard was not censored in accord with the immunity fron censorship extended legally qualified political candidates."); N.Y. Crvm RrGHTs LAw \& 75 (must announce that the remarks of the candidate are not to be construed as reflecting the opinions, bebiefs, etc. of the stations, its ownership or management). (3) A third type of limitation is that the immunity is lost if the defamation is uttered by the owner, licensee, or employee of the station in the course of his employment: e.g., MIss. CoDE ANN. § 1059.5(2) (1956). But cf. ConN. GeN. STAT. ANN. § 52-239 (1958) (owner of station must have participated wilfully, knowingly and with intent to defame in order to forfeit the immunity).

In Maryland, the broadcaster is liable only for compensatory damages in any case where a candidate for public office defanies another not a candidate for public office, MD. CODE ANN. art. 75, \& 6(b) (1957).

82 See 44 MnNo. L. REv. 787, 789 (1960). Only five states (Alabama, Alaska, Delaware, Rhode Island, and Vermont), the District of Columbia, Guam, Puerto Rico, and the Virgin Islands lave never enacted any legislation affecting the broadcaster's liability. Ilinois comes close to having no specific treatment by putting everything under the penal code. To be liable for criminal defamation, one must intend to defame. It was obviously the purpose of the legislature to bring slander by means of radio and television within the statute. IrL. Stat. AnN. 38 \& 27-1 (1961). 
immunity actually accorded under state law might never have been so broad. ${ }^{83}$

The wave of state legislation in the late 1940's was significant in quite another way. We have already observed how much time and energy were spent debating libel vs. slander and publisher vs. bookseller, and some of the consequences of that unfortunate diversion. What makes the debate the more unfortunate is that while the debaters argued, the courts and the legislatures were quietly resolving or removing the debated issues. This was done in several ways: The facts of many of the cases made the libel-slander issue irrelevant. ${ }^{84}$ To the extent that the facts did not moot the debate about these questions, the statutes helped to do so. Many legislatures, before they did anything else in this area, decreed that radio defamation was either libel or slander (usually libel) or without the label, gave it the unmistakable legal characteristics of one or the other. Many of the statutes also resolved the standard-of-care questions. A common provision, for example, gave complete immunity to the broadcaster who had exercised ordinary care except when his own employee was at fault. ${ }^{85}$ Under laws of this sort; it made no difference whether

83 The arguments for absolute liability were most forcefully advanced by Prof. Lawrence Vold. See Vold, Defamation by Radio, 2 J. Rabro Law 673 (1932); Vold, Defamatory Interpolations in Radio Broadcasts, 88 U. PA. L. Rev. 249 (1940).

84 In some cases the allegations would lave been actionable either as libel or as slander, for example, because they fell into one of the "per se" categories, e.g., Lynch v. Lyons, 303 Mass. 116, 20 N.E.2d 953 (1939); in others the distinction was immaterial because recovery could not be lad under either rubric, e.g., Barry v. Kirkland, 149 Neb. 839, 32 N.W.2d 757 (1948). The standard of care also became superfluous in a number of cases-ither because the broadcaster liad sliown a lack of ordinary care, e.g., Riss v. Anderson, 304 F.2d 188 (8th Cir. 1962); or because the offense was committed by one of the broadcaster's own employees, for whose torts he was responsible under ordinary agency principles, e.g., Miles v. Louis Wasmer, Inc., 172 Wash. 466, 20 P.2d 847 (1933).

85 Present state legislation on this question reveals many variations when the speaker is someone other than the broadcaster or a person in his employ. As for burden of proof, there are four distinct types: (1) The broadcaster is liable where the plaintiff alleges and proves a failure of the station owner or an employee to exercise due care to prevent the defamation, e.g., W. VA. CODE § 5482(1) (1961); S.D. CodE § 47.0506 (Supp. 1960). (2) The exercise of due care is presumed, in some manner, from a bona fide compliance with federal regulations and laws, e.g., ArIz. Rev. Stat. § 12-652 A Supp. 1953; K¥. Rev. Stat. $\$ 411.062$ (1956). (3) The broadcaster is liable unless he alleges and proves the exercise of due care with respect to the defamatory broadcast, e.g., Onto CODE ANN. § 2739.03(B) (1953); NEB. Rev. Stat. $\$ 41.340$ (1961). (4) The broadcaster in one state is liable where the plaintiff alleges lack of due care unless the broadcaster proves the exercise of due care, TeNN. CODE ANN. § 23-2606 (Supp. 1964).

The degree of culpability necessary for liability also differs: (1) In two states there is no mention that the immunity is conditioned upon a degree of culpability, MIss. CoDE ANN. § 1059.5 (1956); N.D. CENT. CODE § 14-02-09 (1959). (2) See statutes cited supra note 85 , where broadcaster must exercise due care in order to come within the immunity. (3) Some states loold the broadcaster liable only upon proof of actual malice relating to the defamation, e.g., IDAFO CODE $\$ \S 6-706,6-708$ (1947). 
one called the broadcaster a "publisher" or a "disseminator," for the only legal consequence to which that classification was pertinent had by legislation been removed from the realm of dispute. It would be unfair to suggest, of course, that these issues were easy simply because the legislatures could settle them so readily. It is enough to point out that it became ever more pointless to debate the old issues as thougl the common law was the only guide to decision. It was the increasing futility of these controversies that made them particularly unfortunate.

Finally, the preoccupation with nearly dead issues overshadowed two further matters that should have received prominent attention. First was the nature and unique impact of radio, and later of television, as communication media. The inapplicability of the old libel-slander criteria should lave made it obvious that radio was different in many ways relevant to tort liability. Those differences were soon to intrigue social psychologists and others in the behavioral studies. ${ }^{80}$ In terms of the number of hours each day the set played in the average home, the irrational devotion of fans to their favorite programs, and the quite rational dependence upon the radio for news and information and contact with vital public events-in terms of all these, radio as a medium presented entirely new and different considerations as the backdrop to tort liability. And whatever could be said of radio, it was even more true of television, for studies have slown how much greater is the impact of a particular communication when received througl the senses of sight and sound simultaneously

Another test of liability is used in a few states. The broadcaster may require advance copy of the proposed script. If he does so, he is immune from hability for any defamatory matter actually broadcast which is not contained in the script, e.g., Fra. STAT. ch. 770.03 (1959); WaSH. Rev. Code ANN. \& 19.64.010 (1961).

Furthermore, the extent of damages recoverable in any suit against the owner, operator, licensee or employee is defined by some statutes. The plaintiff is sometimes limited only to actual damages, e.g., LA. Stat. Ann., Rev. Stat. tit. 45, § 1353 (1950); Neb. Rev. Stat. § 86-603 (1958); ARIz. REv. Stat. ANN. \& 12-652(c) Supp. 1953. Other states specifically prescribe the recovery of pumitive damages, e.g., OKLA. Stat. ANN. tit. 12, § 1447.3 (1951). Broadcasters are given an opportunity to retract in some jurisdictions. Statutes usually set forth standards which the retraction must meet. If a retraction conforms to the standards, and if the defamation was made without an intent to defame and in good faith, retraction will limit the plaintiff's recovery to special damages, in some jurisdictions, and merely go to mitigation damages in others, e.g., Cax. Crv. Code § 48a; N.C. Gen. Stat. §§ 99-I(b), 99-2 (b) 1943; OrE. Rev. Stat. § 30.160 (1961).

${ }^{86}$ For a fascinating detailed case study of the radio broadcast of Orson Welles' "Invasion from Mars," which clearly illustrated how powerful was the grip of radio upon its audience, see CantrII, Gaudet \& Herzog, Invasion from Mars (1940). A later case study reinforced and underscored the persuasive power of radio as a communication medium, Merton, Fiske \& Curtis, Mass Persuasion: The Soctal Psychology of a War Bond Drrve (1946). Other materials may be found in Hovland, LonssdanNe \& SHEFrietd, Exper-

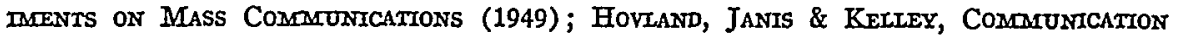
and Persuaston (1953); Lazarsfeid \& Stanton, Communtcations Research 1948-49 (1949); Lazarsfeid \& Kendadx, Radio ListendNg in AMgerica (1948). 
than through either alone. ${ }^{87}$ But the law of defamation was shockingly ill-equipped to cope with the tortious potential of television. For years courts and commentators found little to differentiate the new broadcast medium from the old.

The second oversight is perhaps less distressing than the first. During the years of radio, defamation was the principal ground of litigation, although there were a few cases involving various forms of unfair competition and copyright infringement. Since the age of television, however, invasion of privacy has become at least as important a source of tort liability for broadcasters as defamation. ${ }^{88}$ And the questions raised by the privacy suits may be even more difficult to analyze, and more troublesome in terms of public policy. The burgeoning of television privacy litigation is important here for two reasons: First, looking to the past, the difficulty the courts liave had in coping with these new cases seems im part a consequence of the same preoccupation that immobilized the law of broadcasting liability in the defamation area; and second, with an eye to the future, any discussion of proper standards of liability can no longer overlook the impact of this newer branch of tort law upon broadcasting.

\section{B. The Search for Workable Standards}

Enough has been said to show the need to fashion or clarify comprehensive principles of liability. Many problems still demand analytical solution. If, therefore, we repudiate the libel-slander distinctions, and the pointless quest for analogies, there is a need to recast the analysis in more unodern, more workable terms. These new terms should combine two characteristics which may at first seem incompatible: On the one liand, they inust be general enough to deal with privacy claims as well as defamation suits, and possibly other related torts that involve reputation, character, or feehings. On the other hand, new criteria must be capable of particular application to cases the facts of which vary greatly; that is, they inust avoid the rigidity of analysis that led in the 1930's to the generalization of broad principles from a few early cases that soon proved to be unrepresentative. With these general considerations in

87 See, e.g., Steiner, The Prople Look At Terevision: A Study of Audience AtimTUDES (1963); Rose, Attitude As A Function of Discrepancy Resolution in Multiple Channel Communication (Unpublished $\mathrm{Ph} . \mathrm{D}$. dissertation, Stanford University, 1964), pp. 22, 26; Elliott, Memory for Visual, Auditory and Visual-Auditory Material, 29 Arcarves of PsyCHOLOGY 199 (1936); Hartman, Single and Multiple Channel Communication: A Review of Research and A Proposed Model, 9 Audio-Visual Comamunications Rev. 235 (1961); Koch, Some Factors Affecting the Relative Efficiency of Certain Modes of Presenting Material for Memorizing, 43 AN. J. Psycrology 370 (1930).

88 See cases cited notes 8-11 supra. 
mind, it is now time to consider some general principles of broadcaster's liability.

\section{Source of the Offending Material}

A broadcaster may incur tort liability from material that is either contained in a prepared script or unexpectedly interjected during a broadcast. The latter category includes that which is ad libbed during a broadcast based upon a written script, and that which occurs during a program for which no script could have been prepared (interviews on the street, sporting events, spot news coverage, and the like). The presence of offending material in the script would appear relevant not so much to the old question whether defamation is to be treated as libel or slander, but rather to the more meaningful question of which parties are to be held liable and to what degree.

For example, the broadcaster's liability slould be beyond doubt where a script has been submitted and reviewed in advance. The other participants in the preparation of the program are also presumably hable, at least in the absence of some good excuse-the sponsor, the producer, the advertising agency, the station representative and perhaps others. For these parties, it should make little difference whether the standard be one of strict liability or of negligence, for a lack of due care could presumably be shown.

In its very nature it might appear that an invasion of privacy could arise only froun a script. To date most of the cases have been of this sort. But privacy claims could arise from coverage of spot news events, or sporting events, or of various forms of entertainment (such as the filming of a nightclub audience). ${ }^{89} \mathrm{~A}$ recent Florida case presented just this

80 See Freedon of Information Center, Turbulence in the Privacy Fieid 3-4 (Pub. No. 133, 1964); Yoder, "Be Good! Television's Watching," Sat. Evening Post, May 14, 1949, p. 24; Note, The Right of Privacy and Television, 28 Notre DAME LAw. 389, 397 (1953); cf. Franklin, A Constitutional Problem in Privacy Protection: Legal Inhibitions on Reporting of Fact, 16 STAN. L. Rev. 107, 117-21 (1963). Several courts have refused to find actionable invasions of privacy in telecasts of public or semi-public events in which the plaintiff was a willing and knowing participant, even though he may have been unaware of the presence of the TV camera, Gautier v. Pro-Football, Inc., 304 N.Y. 354, 107 N.E.2d 485 (1952); Chavez v. Hollywond Post No. 43, American Legion, 16 U.S.L. WeEk 2362 (Cal. Super. Ct. Feb. 3, 1948); Peterson v. KMTR Radio Corp., 18 U.S.L. WEex 2044 (Cal. Super. Ct. July 26, 1949). Recently one television station, apparently concerned about possible hability under such circumstances, refused to broadcast the names, pictures, voices, and statements of various public figures (President Truman, Ambassador Adlai Stevenson, Eleanor Roosevelt and others) during a controversial state campaign over a right-to-work law proposal. The General Counsel of the FCC prepared a legal memorandum concerning the applicable state law and its effect upon the broadcaster's possible liabihties. See Geller, A Legal Memorandum: "Right to Privacy" Statutes and Case Law, 12 FED. B. News 6 (1965). The memorandum concludes that a broadcaster could not incur liability under the 
situation. ${ }^{00}$ The plaintiff was an innocent bystander during a gambling raid on a cigar store. The event was filmed by a local television station and portions of the films were broadcast during an evening news program. The plaintiff's proximity to the raid insinuated, he claimed, some association with the illicit activities. But the court rejected the claim, influenced partly by the strong public interest in the prompt and unfettered dissemination of news material. ${ }^{91}$ Nevertheless there is the distinct possibility that a suit of this sort will eventually succeed on privacy grounds.

When the offending material is contained in a script, there are two further questions. It may be that the station failed for some reason to review the script before the broadcast. If so, it should be determined why no better precautions were taken. And if no explanation comes forth, it might be reasonable to presume that since an opportunity for review existed the unexplained failure to delete the offending content would furnish the basis of liability. ${ }^{22}$ The other situation is a bit harder, though. Where the injury could not have been anticipated, even by a prudent broadcaster, from the text of the script, it will be necessary to determine whether the broadcaster, like the publisher, is nevertheless strictly liable regardless of his innocence. The answer to this question should depend not on any factual analogy between broadcasting and publishing, but rather on the special policies that are relevant to the balancing of particular interests among the various parties. That question invites a closer examination of other factors.

\section{Relationship Between the Speaker and the Broadcaster}

More troublesome than the offending script is the case of the defamatory ad lib of which the script (if there is is one) affords no warning. In this case the relationship between the broadcaster and the speaker becomes inportant. We assume that the speaker, at least, is always liable.

applicable state law for the use of statements by and news clips about such public figures as those involved in the right-to-work law case.

${ }^{80}$ Jacova v. Southern Radio \& Television Co., 83 So. 2d 34 (Fla. 1955).

01 Id. at 40. For expressions of similar cautions by other courts, see Charles Parker Co. v. Silver City Crystal Co., 142 Conn. 605, 616-17, 116 A.2d 440, 445 (1955); Dale Sys. v. General Teleradio, Inc., 105 F. Supp. 745, 751-52 (S.D. N.Y. 1952); Gearhart v. WSAZ, Inc., 150 F. Supp. 98, 107 (E.D. Ky. 1957), aff'd, 254 F.2d 242 (6th Cir. 1958); Summit Hotel Co. v. NBC, 336 Pa. 182, 202-03, 8 A.2d 302 (1939).

92 These were essentially the facts in Sorensen v. Wood, 123 Neb. 348,243 N.W. 82 (1932), although the court's acceptance of the principle of absolute liability made it unnecessary to consider the possible effect of the unexplained failure to review the script which was available prior to the broadcast. It is noteworthy that the statutes of several states provide that the broadcaster may demand a script in advance of the scheduled broadcast and, llaving reviewed the script, will not be liable for any defamatory utterances that go over the air which did not appear in the script. See, e.g., FLA. STAT. cli. 770.03 (1961); WASE. REv. CODE ANN. \$ 19.64.010 (1961). 
If he is an employee of the station, then the broadcaster's hability follows from general principles of agency law. More common is the case in which the speaker, although invited and scheduled to use the facilities, is not an employee of the station, nor otherwise formally associated with the broadcaster. In this situation, unless the broadcaster's liability is absolute, a court might consider whether reasonable care was exercised in selecting or scheduling the speaker. Where such care lias been exercised, it may be unduly harsh to hold the broadcaster liable. ${ }^{03}$

Another "ad hb" case involves a speaker who is neither an employee nor a scheduled user of the station. In this category are the impromptu interview with the man on the street, or the remark shouted in the sports arena or overheard during coverage of a Presidential inauguration. Here it may be possible to show some lack of care by the broadcaster or his staff-for example, in having left open a microphone in the crowd that should have been turned off, or in inviting too many unknown and untested persons to participate in street-corner symposia. But where no such lack of precautions can be shown, there seems an insufficient basis for the broadcaster's liability.

\section{Timing of the Broadcast}

Surely it should make a difference whether the offending program is being broadcast "live" or by delayed transmission. The live broadcast gives the station little or no chance to protect itself against possible liability, and there are many instances in which live or simultaneous broadcasting is desirable if not essential, particularly in the sustained coverage

93 See statutes cited note 85 supra, for a survey of the various ways in which this situation has been handled by the state legislatures. Any criterion of this sort raises, of course, difficult issues as to what constitutes "reasonable precautions" or "due care" on the part of a broadcaster. Undoubtedly the question would be referable in large part to prevailing industry practices, although the industry should not be able simply by custom to lower the requisite standard of care unduly. Cf. The T. J. Hooper, 60 F.2d 737 (2d Cir. 1932), cert. denied sub nom. Eastern Transp. Co. v. Northern Bargs Co., 287 U.S. 662 (1933). For some of the pertinent precautions that might be expected, see Remmers, supra note 77 , at 742-44.

An executive of one of the major issuers of broadcast defamation insurance reports: "We have always urged the particular use of care by broadcasters and the use of such devices as recording apparatus and the requirement of advance copies of speeches for whatever value they may be in minimizing hbel losses and claims. This, of course, is a continuing effort." Letter from Reginald Geiser, Assistant Vice President, Employers Reinsurance Corp. to the Author, March 4, 1965.

A major network executive responds that "most of the larger broadcasters, particularly the networks, do have their own legal departments, whose function it is to review material for broadcast in an effort to prevent the broadcast of any defamatory material or any material invading rights of privacy." Letter from Mortimer Weinbach, Vice President, American Broadcasting Co. to the Author, March 26, 1965. 
of important news events. ${ }^{94}$ Here it would seem severe to penalize the broadcaster for trying to bring news and special events to the audience as fast as possible.

The suggestion has been made that the broadcaster may guard himself, even during the live broadcast, by alerting his engineers to cut off immediately any program in which defamatory material is detected.95 One system used, especially in the ad libbed interviewing situation, employs a tape delay mechanism whicl allows a delay of several seconds between the time the words are uttered and the time they are broadcast. This affords only partial protection, however, for there are several mitigating factors: First, and perhaps most obvious, is the difficulty in identifying actionable defamation ${ }^{96}$ second, the ad libbed defamation typically involves only a few seconds of air time; ${ }^{97}$ and third, excessive zeal in monitoring of this sort would quite likely produce an undesirable degree of selfcensorship contrary to the public interest. ${ }^{98}$ Tlius the broadcaster's only effective precaution would seem to be to record all programs for delayed broadcast. That alternative may not only mcrease cost significantly, but may also forfeit the advantages of rapid live transmission of current events.

\section{Source of the Broadcast: Network or Local}

Offhand it miglit appear that the broadcaster has mucl greater control over programs originating in his own studios than over those received from the network wires or cables. ${ }^{99}$ But this is true only where

94 A major network president has recently commented upon the difficulty of painstaking precautions in the handling of spot news and feature material: "Because you have to maintain speed, you particularly need responsible people on television. . . . There is httle or no time to edit a fast-breaking story. You rely on the ability and judgment of the man on the scene whose "copy' goes direct to the viewers at home." Kintner, "Broadcasting and the News," Harper's, April 1965, p. 49, at 52.

95 Sorensen v. Wood, 123 Neb. 348, 353, 243 N.W. 82, 85 (1932); McDonald \& Grimshaw, Radio Defamation, 9 AR L. Rev. 328, 332 (1938).

90 See Graham, Defamation and Radio, 12 WASH. L. Rev. 282, 289 (1937).

97 See Davis, Libel and Slander by Radio, 34 CASE \& CoMarent 67, 70 (1928).

98 See Guider, Liability for Defamation in Political Broadcasts, 2 J. Radio Law 708, 712 (1932).

99 Some states provide by statute that where a defamation is broadcast over two or more radio or television stations in a network, hability is restricted to the originating station, e.g., Idamo Code § 6-709 (Supp. 1963); Mont. Rev. Code § 64-207 (1953). See also statutes cited supra note 88 , where the broadcaster is hable if he fails to exercise due care. Where a network program is broadcast hive, it would be difficult to say that the broadcaster was neghigent in allowing the broadcast of a defamation. Another circumstance is where the network program is taped and broadcast is delayed for a time. It is theoretically possible to place on the broadcaster the burden of viewing each such taped program in order to edit any defamatory matter. Considering the bulk of network material, however, broadcasters could well be heard to argue that such a burden would weigh too heavily on them. See Broadcasting, March 22, 1965, p. 48, for the current controversy over a 
the network material is transmitted simultaneously; if it is taped upon receipt and delayed, then obviously it is subject to the same scrutiny as pre-recorded local material. The network affiliation contract typically requires the local affiliated station to carry a certain amount of network material. ${ }^{100}$ Thus there is some question about the flexibility of the local stations in rejecting or selecting among network material, and it would not, of course, be easy to find a last-minute local substitute for a network program that presents possible tort liability. Because of these and other problems presented by network broadcasts, the courts might in the future examine more closely the particular legal relationship between network and affiliate. Such examination has been undertaken in other contexts, ${ }^{101}$ but has seldom been applied to the tort field.

\section{Sponsorship of the Broadcast}

The offending program may have been commercially sponsored or it may have been carried by the station or network as "sustaining" material to which a certain amount of time must be devoted. ${ }^{102}$ This distinction should probably have no effect upon the broadcaster's own liability. But where the program is sponsored, there are obviously more difficult questions regarding the liability of persons other than the broadcaster.

The fact of commercial sponsorship is not necessarily relevant to the sponsor's actual participation in the preparation of the program. Some programs are prepared largely under the sponsor's own supervision. Others are left almost entirely to the advertising agency, with only occasional consultation of the sponsor for high-level decisions. ${ }^{103}$ In recent years there has been an increasing tendency to assign the preparation

proposed FCC ruling to restrict network control of programming. Cf. Kintner, "Broadcasting and the News," Harper's, April 1965, p. 49 at 52-53 for a discussion of the problems of on the spot broadcasting of news and feature material which may also be too difficult to screen. Thus the better solution with respect to network matter would be to follow the example of Idaho and Montana.

100 This statement is, of course, an oversimplification of the relationship between network and affiliated station. It must be qualified in terms both of the economic aspects of network broadcasting, and of the rather tight FCC regulation of the broadcast licensee's relationship with the network. See HEAD, BrondCASTING IN AMERICA 229-32 (1956); Lawton, Tae Modern Broadcaster 109-10 (1961); and for an exhaustive study, sce Columbia Broadcasting System, Network Practices (Memorandum Supplementing Statement of Frank Stanton, President; Prepared for the Senate Committee on Interstate \& Foreign Commerce) (1956)i.

101 See, e.g., NBC v. Umited States, 319 U.S. 190 (1943) ; CBS v. United States, 316 U.S. 407 (1942).

102 For a thorough discussion of the FCC's requirement that a certain portion of every broadcaster's time be allotted to sustaining material, see SMEAD, FrEEdoM of SPEECI BY Radio aNd Television 63-73 (1959).

103 For a description of the role of the advertising agency in television program production, see BarNouw, The Television Writer 26-27 (1962). 
of "packaged" programs to outside producers, with neither the sponsor nor the agency supervising the details. ${ }^{104}$ Even under this arrangement, lowever, a program is unlikely to go on the air without review by either the advertiser or the agency..$^{105}$

Another plienomenon of recent years is that of multiple sponsorship. In the heyday of radio and during the early years of $T V$, the pattern was primarily one of single-sponsor assignment of particular time slots, often actually bearing the sponsor's name. Today the general practice is to share the sponsorship, ${ }^{106}$ with the late eveming variety programs, particularly, presenting a seemingly endless series of unrelated commercial messages. Whatever the reason for its widespread adoption, multiple sponsorship clearly poses new and difficult problems in apportioning liability among a number of possible defendants.

One solution, which has the virtue of simplicity if no other, would be to hold all the sponsors equally liable for any tortious material during the entire program. A second would be to apportion liability according to the proportion of total commercial time devoted to eacli sponsor's wares, on the theory that the benefit derived from the broadcast is roughly reflected in this factor. A third approacl might be to confine liability to those advertisers directly responsible for the particular segment of the program during which the injury occurs. But if it is a matter of chance just when the offending material is broadcast, it seems inequitable to impose liability by so fortuitous a test. Thus the second test would seem the most reasonable-unless, of course, one or more of the sponsors, or lis representative, actually participated in or condoned the preparation of the offensive material.

104 See "Production of TV Shows Shifts More and More to Hollywood," N.Y. Times, March 30, 1965, p. 95, cols. 3-4. For a vivid and colorful description of the increasingly important activities of the outside program "packager," see OpoTowskY, TV: THE BIG PICTURE 128-36 (1961).

105 The leading television columnist of the New York Times has observed, "Actually a television show does not reach the air without the constant involvement of representatives of networks, advertising agencies and sponsors; their relationship with the package producer is sustained and extremely intimate. They are also present at all shows." N.Y. Times, Oct. 12, 1959, p. 39, col. 4. It is a persistent complaint about American television, in fact, that sponsors exercise too much control over program content, to the detriment of quality and cultural level. See, e.g., Siepmann, "What Is Wrong With TV-and With Us?," N.Y. Times, April 19, 1964, VI, p. 13. Compare the British experience, under which the Independent Television Authority (the commercial network) exercises extensive control over programs while the sponsors are theoretically denied any power to supervise program content. See Street, FreedoMr, THe Individual and tHe LAW 79-81 (1963).

$106 \mathrm{See}$, e.g., the patterns of joint sponsorship reflected in preliminary sales of prime evening broadcast time by the three major networks for the 1965-66 season, in "Detailed Wrapup of Fall TV Schedules," Broadcasting, March 1, 1965, pp. 30-32. 


\section{The Medium: Radio or Television}

Whether the tort be defamation or invasion of privacy, it is likely to have far greater impact on television than on radio. In part this is because of the much larger audiences that view almost any TV program. ${ }^{107}$ The greater impact of television results also because the radio audience consists increasingly of casual listeners-automobile drivers, for example, or sunbathers at the beach-who lack the intensity or the preoccupation of the video viewer. ${ }^{108}$ To some extent the greater impact of television can be taken for granted; but it might be appropriate in assessing damages for injury to privacy or reputation to gather relevant behavioral studies measuring the psychological import of this factor. ${ }^{109}$

\section{Retraction}

In many states, special statutes provide for reduction of damages or even a complete defense if the defendant issues a retraction at the plaintiff's request. ${ }^{110}$ Usually the demand must be made within a certain time after the alleged defamation. In some states, indeed, the making of such a demand, and the defendant's failure to accede to it, are prerequisites to the plaintiff's suit.

Retraction statutes have encountered various obstacles. Some state courts, in fact, have held these statutes unconstitutional on various grounds. ${ }^{111}$ Apart from these questions, there is some doubt whether the concept of retraction is even appropriate to broadcasting. The whole theory of a retraction is that it will correct in the minds of the audience the false impression created. The assumption may be sound in the case of a newspaper or magazine, where the readership is fairly stable and

${ }^{107}$ In 1963, for example, during the prime evening hour of 9-10:00 p.m., there were an average of 33.9 million homes viewing television, while only 5.5 million homes histened to the radio during that same hour. Only in the very early morning hours does radio any longer effectively compete with television in audience size. Compare MEDUA RESEArCH Div., A. C. Nieisen Co., Radio '63 10 (1963), with Media Resenrch Div., A. C. NIEISEN Co., TELEVISION '63 8 (1963).

108 In summer, more than half the average weekly hours of radio listening involve hattery portables and automobile radios; for the winter months, the average figure is only slightly less than half. See Media Research Div,, A. C. NIEIsen Co., Radio '63 9 (1963).

100 See materials cited note 86 supra.

110 See, e.g., CAL. Crv. CODE § 48a. The general formula of such statutes is to permit recovery of general damages only if a retraction is demanded within a certain time after the offending broadcast, and if the retraction is not issued thereafter. Some also provide that general damages may be recovered despite the issuance of a retraction if a specific intent to defame can be establisled by the plaintiff, e.g., OrE. REv. Stat. § 30.160 (1961).

111 E.g., Park v. Detroit Free Press Co., 72 Mich. 560, 40 N.W. 731 (1888). For a thorough discussion, pro and con, of the constitutionality of retraction statutes as applied to broadcasting, see Holden v. Pioneer Broadcasting Co., 228 Ore. 405, 365 P.2d 845 (1961) (4-3 decision). 
constant, but is questionable in the broadcasting field where most audiences tend to be somewhat more fickle-except perhaps in the case of certain commentators or stars with a fairly constant following. ${ }^{112}$ The problem of issuing an effective retraction is particularly acute in the very kinds of broadcasting where defamation is most likely to occur-special events, news programs, political addresses, panel discussions and the like which are "one shot" broadcasts without a recurrent audience. ${ }^{113}$ Even if a correction is broadcast the next day over the same station at the same time as the original falsehood, the probability of its reaching any substantial portion of the original audience is quite conjectural..$^{114}$

The apphication of retraction, particularly to television, raises several other questions. Where the plaintiff is injured by a dramatic characterization, or by the display of his photograph, can any mere statement ever effectively correct the misimpression? ${ }^{115}$ On the other hand, is there any other form in which the notice of retraction is meaningful? None has been suggested. Perhaps the answer is that even a corrective statement is better than nothing, though obviously inadequate to undo the damage wrought by a defamatory characterization woven into the fabric of a 90-minute drama. There is also a question about the application of the retraction meclianism to privacy suits. Although there would logically appear to be nothing to "retract," one court has suggested that a demand

112 See, e.g., Wanamaker v. Lewis, 173 F. Supp. 126 (D.D.C. 1959), involving a statement of apology by Fulton Lewis, Jr., the radio news commentator, and an admission that he had made a "horrifying mistake" with respect to the plaintiff. The statement was broadcast on Lewis' Monday program following the Friday newscast on which the offending statement appeared, at the very same hour and over the same stations.

113 See Kelly v. Hoffman, 137 N.J.L. 695, 697, 61 A.2d 143, 146 (Ct. Err. \& App. 1948). Because of uncertainties about the appropriateness of retraction to broadcasting, it is not surprising that broadcasters occasionally refuse to comply with a plaintiff's request for a retraction. See, e.g., Charles Parker Co. v. Silver City Crystal Co., 142 Conn. 605, 116 A.2d 440 (1955); Greer v. Skyway Broadcasting Co., 256 N.C. 382, 124 S.E.2d 98 (1962).

114 A possible alternative to retraction which might merit discussion in the broadcasting context is the "right of reply" conferred upon the injured party by the law of many European nations. See Donnelly, The Right of Reply: An Alternative to an Action for Libel, 34 VA. L. Rev. 867 (1948); Riesman, Democracy and Defamation: Fair Game and Fair Comment I, 42 Corus. L. REv. 1085, 1109-15 (1942).

The "right of reply" is essentially the formula employed by the FCC in attempting to redress personal attacks made by a broadcaster upon a public official or political candidate. The Commission's "fairness doctrine" has frequently been held to require the affording of an opportumity for the injured party to respond. See FCC, Applicability of the Fairness Doctrine in the Handling of Controversial Issues of Public Intportance, 29 FED. REG. 10415, 10420-21 (1964).

115 Analogous questions have arisen in the publishing field in determining the sufficiency, for example, of a "retraction" designed to mitigate the effect of a defamatory photograph. See, e.g., Southeastern Newspapers, Inc. v. Walker, 76 Ga. App. 57, 44 S.E.2d 697 (1947). 
for retraction would nevertheless be appropriate, at least where a claim for defamation might also have been made. ${ }^{116}$

\section{Retention of a Record of the Broadcast}

Originally the libel-slander test sometimes turned on the extraneous factor of whether the station had recorded the broadcast. ${ }^{117}$ While this was an attempt to ascertain the "permanence" of form of the defamation, the fact of recording would be of hittle significance unless the program was rebroadcast from the tape. In that case, a subsequent publication of the offending material, particularly after the plaintiff protested, should certainly affect the measure of damages. ${ }^{118}$ Otherwise, it should make no difference whether the broadcaster retained some permanent record of the program. Indeed, the prudent broadcaster may be well advised to keep such recordings to establish in the event of litigation precisely what was said and shown over the air.

\section{Balancing of Public Interests}

The juxtaposition of all these factors does not, of course, produce a neat or simple test of hability. The great merit of the libel-slander dichotomy, the publisher-distributor analogies, and the like, was that they did produce such a test, even if it was not logical or particularly appropriate to the new media. What is suggested here is that the characteristics of these media are so complex and the range of broadcasting situations so broad that courts ought to reject simple tests and consider all the relevant factors. Some of these have already been outlined. A few more remain to be considered.

One element that courts do occasionally, and properly, consider is the strength of the public interest in the defendant's conduct. There is obviously a far greater value in the broadcasting of spot coverage of racial demonstrations, or the aftermath of a presidential assassmation, than in a commercial or a quiz show. Quite apart from the much greater control the broadcaster can exercise over the content of the programs of the latter

116 See, e.g., Werner v. Times-Mirror Corp., 193 Cal. App. 2d 111, 14 Cal. Rptr. 208 (1961). For a suggestion that the suit for invasion of privacy may have been used, or abused, by plaintiffs' attorneys in an effort to circumvent the inhibiting effect of retraction upon defamation suits, see Powsner, Libel in Limbo: Another Conquest for the Right of Privacy?, 30 Los ANgeles B. Bull. 365 (1955).

117 See Note, Damages for Defamation by Radio, 25 CHI.-KENT L. REv. 142, 147 (1947).

118 The originator of the defamatory broadcast would presumably be hable even for a republication by someone else, perhaps even by a listener or viewer who had recorded the program for his own use. On the original publisher's liability for republication, see generally Prosser, TORTS 787 (3d ed. 1964). 
type, the strength of the public interest ought to restrict the broadcaster's liability in those areas affected with the greatest public interest. ${ }^{118}$

On the other hand, the apparent purpose or motive of the particular defendant may be highly relevant. Consider, for example, a recent Pennsylvania case which makes this point. ${ }^{120}$ The plaintiff, operator of a garage and towing service, had been charged with various offenses in connection with a "car-towing racket," and criminal charges were then pending. $\mathrm{He}$ had protested his innocence, and eventually his conviction was reversed on appeal. Before the appeal was argued, however, the defendant radio station scheduled a broadcast, a "news documentary," designed to expose the "racket," which prominently portrayed plaintiff's part in these activities. On the morning of the day of the broadcast, the plaintiff's wife happened to see an announcement of it in the newspaper. She telephoned the station several times to urge that the program be withheld, because she believed her liusband mnocent. Representatives of the station refused, and the program went on the air as scheduled. The court, in sustaining the plaintiff's judgment, was understandably influenced by the broadcaster's callous indifference to the possibly crippling injury it was about to inflict. Thus, whatever privilege the public interest in comment on current news and special events may have conferred upon the broadcaster it was clearly overcome by the defendant's almost malicious conduct. ${ }^{121}$ This sort of balancing of interests and equities seems altogether proper.

FEDERALISM AND THE BROADCASTER'S TORT LIABILITY

Two general observations seem appropriate at the outset. First, the field of tort liability for defamation, invasion of privacy, and other similar claims is only one of several contexts in which the broadcaster may be caught between federal and state law. There has recently been much controversy and some litigation involving two other very important and difficult contexts-community antenna television ${ }^{122}$ and pay tele-

119 See 38 Mich. L. Rev. 415, 417 (1940).

120 Purcell v. Westinghouse Broadcasting Co., 411 Pa. 167, 191 A.2d 662 (1963).

121 It was on this basis that the Pennsylvania court not only rejected all the broadcaster's claims of privilege or immunity, but actually upheld the granting of punitive damages. Here the inference of malice was clear, and the defendant's conduct considerably more odious than that of the broadcaster or publisher who simply refused to issue a retraction upon demand, since here "the request not to defame was made before the publication of the libel." Id. at 185-86, 191 A.2d at 671-72.

122 The leading case concerning community anterina television is Cable Vision, Inc. v. KUTV, Inc., 335 F.2d 348 (9th Cir. 1964). Community antennas have gone generally unregulated by the FCC. See Note, Community Antenna Television: Survey of a Regulatory Problem, 52 GEO. L.J. 136 (1963). It now seems quite likely, however, that the FCC will 
vision. ${ }^{123}$ In the next decades these areas may well present more problems and cases than those we have been considering here. But for the moment the inaterial in the tort field is far richer. It seems appropriate to attempt to fashion here some principles of federalism that may later be carried over to aid in the solution of the difficult problems that are almost certain to arise elsewhere.

Federal law inpinges in several ways upon the broadcaster's activities. Most obvious is the impact of federal regulation under the Federal Communications Act of $1934 .{ }^{124}$ Less obvious is the relevance of the first amendment, quite apart from the very controversial "censorship" issues under the Communications Act. Still less apparent is the impact upon the broadcaster of the federal law of copyright and unfair competitionwhich under recent Supreme Court decisions may partially displace state law covering the same fields. ${ }^{125}$ It would be impossible, or at least ill-advised, to judge the broadcaster's potential tort liability under state law without taking careful account of each of these important branches of federal law. We begin with a consideration of the first amendment.

\section{A. The Broadcaster and the First Amendment}

Almost since the beginning of federal regulation of radio, the broadcaster has sought refuge in the first annendment. The principal contention has been over regulation of program content-whether taking past program performance into account in license renewal proceedings infringes either upon the first amendment's gilarantees of free expression or on the Communications Act's own non-censorship section. The courts have consistently rejected the broadcaster's claims in this area, although seldom facing the constitutional issue squarely. These questions are surely worth a full article by themselves, and they have received extensive treatment elsewhere. ${ }^{126}$ Our concern is with a totally different interaction between broadcasting and the first amendment.

The immediate question of how far the first amendment protects

soon assert general regulatory authority over CATV systems. See Broadcasting, March 29, 1965 , p. 5.

123 See Freedoas of Imforaration Center, The Toths of Pay Television, (Pub. No. 136, 1965).

12448 Stat. 1064 (1934), as amended, 47 U.S.C. § 151 (1958).

125 Sears, Roebuck \& Co. v. Stiffel Co., 376 U.S. 225 (1964); Compco Corp. v. DayBrite Lighting, Inc., 376 U.S. 234 (1964).

126 See generally SMEAD, op. cit. supra note 102 , ch. 2. For an extensive memorandum on the authority of the FCC to take account of program content in exercising its licensing function, see Rosenblum, Authority of the Federal Communications Commission, in Coons, FreedoMA \& ResponstBIIITY IN Brondcasting 96 (1961). For a recent discussion of the problem and a collection of pertinent materials, see Note, Regulation of Program Content by the FCC, 77 HARV. L. REv. 701 (1964). 
the broadcaster against state tort liability begins with the Supreme Court's 1964 decision in the New York Times libel case. ${ }^{127}$ The Court there held that a newspaper could not be liable, under the first and fourteenth amendments, for the publication of defamatory statements about a public official unless they liad been made with actual inalice or with a reckless disregard for the truth. An independent examination of the material in question (an editorial advertisement criticizing the police response to civil rights demonstrations in Montgomery, Alabama) assured the Court that neither malice nor recklessness could be proved. This was the view of six inembers of the Court. Three Justices ${ }^{128}$ would liave gone further and would have immunized under the first amendment all suits by public officials against critics of their official conduct, regardless of proof of malice. ${ }^{129}$

There can be no question that the Times decision is relevant for the broadcaster. ${ }^{130}$ Whatever distinction may persist between libel and slander surely cannot liave constitutional significance; the immunity must apply as much to the spoken as to the written word. The case is therefore quite significant because a high percentage of the radio-TV defamation cases liave been suits by public officials against critics who liave taken to the air. Thus, the inevitable conclusion that the Times doctrine applies as much to broadcasting as to publishing at once removes a substantial segment of the broadcaster's potential tort liability.

It should be noted, however, that the himitations of the Times decision are as important as its protections: The case concerns only charges agaimst public officials, thus probably excluding private citizens who are merely candidates for public office, and even at that exempts only comment upon their public acts. ${ }^{131}$ Thus a false account of the mayor's nightly trysts would enjoy no constitutional immumity. Nor is there, under the majority view, any immunity for statements made with actual malice or in reckless disregard of the truth. There is, of course, a question whether

127 New York Times Co. v. Sullivan, 376 U.S. 254 (1964).

128 Justices Black, Douglas, and Goldberg.

128 Justice Goldberg, with whom Justice Douglas joined, concluded his concurring opinion with an expression of his conviction "that the Constitution accords citizens and press an unconditional freedom to criticize official conduct." 376 U.S. at 305.

130 See Kennedy v. Mid-Continent Telecasting Co., 193 Kan. 544, 394 P.2d 400 (1964), in which the court found sufficient allegations of actual inalice to overcome the New York Times privilege. For a suggestion that the Times decision may even be of considerable aid to broadcasters in their "censorship" battle with the FCC, see Editorial, Broadcasting, March 16, 1964, p. 110.

131 Throughout the majority opinion in the New York Times case, the Court stressed the phrase "official conduct" in defining the bounds of the privilege. See 376 U.S. at 272, 273, 279, 283. See also Pedrick, Freedom of the Press and the Law of Libel: The Modern Revised Translation, 49 CORNELL L.Q. 581, 593-94 (1964). 
even in a case in which malice could be shown on the part of the speaker, the broadcaster might nevertheless invoke the constitutional immunity. No cases have yet considered the question, but it would seem that the constitutional defense ought to be separately available to each defendant, so that a lack of individual malice or recklessness would afford any other defendant a privilege even though it would not, of course, immunize the speaker. Thus, whatever may be the standards of care under state law, the broadcaster should enjoy federal immunity from liability for any defamation of a public official over his facilities which has occurred despite due care in the selection of speakers and preparation of the program, even though the speaker himself may have been reckless or malicious.

The field of invasion of privacy suggests a further application of the first amendment to the broadcaster. Although no constitutional defense has yet been recognized as a bar to privacy suits, one court has found at least some himitation in the first amendment. ${ }^{132}$ Such caution seems particularly appropriate where the alleged invasion involves no commercial exploitation or appropriation of the plaintiffs' interest, but only his portrayal, for example, as a figure in a drama, or the presentation of his picture during an on-the-spot news report. There are two reasons why privacy suits may be more vulnerable under the first amendment than suits for defamation. First is the relative recency of the privacy action, having been developed by the courts about a century after the adoption of the first amendment, in contrast to the law of libel, which long antedated the Bill of Rights. The other consideration is the unavailability of truth as a defense to privacy claims. The relevance of this difference has recently been stressed by one commentator: "The interest in compensating plaintiffs who suffer as the result of false statements can be no weaker, and is probably stronger, than the interest in compensating a plaintiff who suffers as the result of a true statement."

A particularly forceful constitutional objection can be made to the injunctive and criminal remedies that occasionally accompany legislative recognition of the right of privacy. It is a crime in some states, for example, to disclose the name of the victim of a sexual assault, and such a statute has been apphed to at least one broadcaster. ${ }^{134}$ The New York

132 Jacova v. Southern Radio \& Television Co., 83 So. 2d 34, 40 (Fla. 1955). See generally Franklin, A Constitutional Problem in Privacy Protection: Legal Ishibitions on Reporting of Fact, 16 Star. L. REv. 107 (1963) ; cf. Franklin, The Origins and Constitultionality of Limitations on Truth as a Defense in Tort Law, 16 STAN. L. REv. 789 (1964).

133 Franklin, $A$ Constitutional Problem in Privacy Protection: Legal Inhibitions on Reporting of Fact, 16 StAN. L. Rev. 107, 140 (1963).

134 Nappier v. Jefferson Standard Life Ins. Co., 322 F.2d 502 (4th Cir. 1963). In this case the criminal statute was used as a source of private remedies in a civil suit for 
privacy statute expressly provides for injunctive relief against anticipated invasions. ${ }^{135}$ Under this provision, one court enjoined, on the eve of broadcast, a national network program because it found therein an invasion of the plaintiff's interests. ${ }^{136}$ Although the plaintiff's consent had been sought, the consent he gave was legally insufficient under the statute. An eleventhhour injunction of this sort would be a harsh sanction even to the newspaper or magazine publisher. Its effect on the broadcaster, whose airtime is much more rigorously scheduled than the publisher's columns, could be disastrous. Even where there may be doubt about the adequacy of the remedies at law, the first amendment, with its abhorrence of prior restraint, should permit the broadcast to proceed and relegate the plaintiff to a subsequent suit for damages. Otherwise the trial court of one state could easily deprive the entire national audience of the chance to watch a program which might well not be actionable anywhere else.

The dangers which libel and privacy suits pose to the free discussion of public issues on the air have not gone unnoticed. With a prescience characteristic of all his writing, Zachariah Chafee once warned of the effect that heavy liability might have upon the tendency toward selfcensorship in the newer media. ${ }^{137}$ Recently the courts have echoed a similar concern. "Courts must be careful," warns one recent Connecticut decision, "not to permit the law of libel and slander to encroach unwarrantedly upon the field of free public debate."138 With reference to the broadcaster's obligation to gather and present material of vital public interest, a federal district judge has warned that "courts should not, by their judgments, hamper or discourage full and free discussion of public busmess or circumstances connected with it."139 The point has been made elsewhere but these illustrations will suffice. Thus even where the New York Times decision supplies no complete privilege to the broadcaster, the first amendment should at least deter any court asked to grant criminal or mjunctive rehef under state law against a broadcaster. And even where the only claim is for damages, the strong public interest in untrammeled presentation of the news and free discussion of current affairs should caution against the award of excessive damages or, im some circumstances,

damages. For a criminal prosecution against a newspaper publisher under such a statute, see State v. Evjue, 253 Wis. 146, 33 N.W.2d 305 (1948).

135 N.Y. CIV. RIGHTS LaW $\$ 51$.

136 Durgom v. CBS, 29 Misc. 2d 394, 214 N.Y.S.2d 752 (Sup. Ct. 1961). This decision was apparently never appealed, and it is not known whether or not the broadcast ever occurred.

137 See Chafee, Free Speech in the United States 522 (1941).

138 Charles Parker Co. v. Silver City Crystal Co., 142 Conn. 605, 615, 116 A.2d 440, 445 (1955).

139 Gearhart v. WSAZ, Inc., 150 F. Supp. 98, 107 (E.D. Ky. 1957), aff'd, 254 F.2d

242 (6th Cir. 1958). 
against any liability at all. Finally, future cases may well extend the New York Times doctrime beyond the facts of that case to encompass the whole field of public affairs discussion. ${ }^{140}$ If the newspaper and magazine publisher are eventually to enjoy such a broad privilege, there can be no question that the broadcaster will share in its enjoyment.

\section{B. The Broadcaster and the Communications Act: Federal Preemption or Displacement of State Remedies}

Few problems posed by the American federal system are more perplexing than the federal preemption or supersession of state remedies. ${ }^{141}$ The problem arises in many contexts, but is particularly acute when federal administrative regulation overlaps state tort law. Seldom does a federal regulatory scheme completely displace state law. Yet the survival of all state remedies could cripple any comprehensive federal regulatory scheme. Between these two easy extremes lie the difficult cases. The analytical challenge is to develop a framework that will resolve these intermediate cases.

A few courts have suggested that Congress intended the Communications Act to occupy the entire field of broadcasting, ${ }^{142}$ but there is little support for the suggestion either in the terms or legislative history of the statute. The Supreme Court has recognized, for example, that the states remaim free to adjudicate various contract and property interests indirectly affecting broadcasters, ${ }^{143}$ although in so doing they must be sensitive to possible abrasions with federal law. Tlus the state courts may enforce a contract for the sale of broadcasting time. ${ }^{144}$ They may not, lowever, decree specific performance of a contract for the sale of a radio station wliere such transfer lias been forbidden by the FCC. ${ }^{145}$

Except for such easy cases, however, the line between federal regulation and state remedies was badly blurred until 1963. On the last day of

140 See Pedrick, supra note 131, at 599.

${ }^{141}$ In view of the substantial amount of litigation, and the obvious importance of the question, there has been remarkably little scholarly writing about federal preemption of state remedies. The best recent treatment seems to be Note, Pre-Emption as a Preferential Ground: A New Canon of Construction, 12 Stav. L. Rev. 208 (1959).

142 E.g., Allen B. Dumont Labs. v. Carroll, 184 F.2d 153, 156 (3d Cir. 1950); Standard Radio \& Television Co. v. Chronicle Pub. Co., 182 Cal. App. 2d 293, 6 Cal. Rptr. 246 (1960).

143 See Note, State Regulation of Radio and Television, 73 HARY. L. REv. 386, 400-01 (1959).

144 See, e.g., ABC v. American Mfrs.' Mut. Ins. Co., 42 Misc. 2d 939, 249 N.Y.S.2d 481 (Sup. Ct. 1963); Southwest States, Inc. v. Woodard, 379 S.W.2d 120 (Tex. Civ. App. 1964).

145 Compare, e.g., Regents of N.M. College v. Albuquerque Broadcasting Co., 158 F.2d 900, 905 (10th Cir. 1947), with Regents of the Univ. Sys. of Ga. v. Carroll, 338 U.S. 586 (1950). 
its 1962 Term, buried between important antitrust cases and decisions involving school prayers and Bible reading, the Court made its most important pronouncement to date on the federal-state relationship in radio and TV broadcasting. The case involved an appeal by a broadcaster from a New Mexico Supreme Court decision sustaining an injunction against any advertising of eyeglass prices and certain other information, over the air. ${ }^{146}$ Such advertising was clearly forbidden by a general state law. ${ }^{147}$ The state court had rejected claims of preemption under both the Federal Communications Act and the Federal Trade Commission Act, and dismissed the broadcaster's challenge under the commerce clause and the first amendment.

The Supreme Court, in Head v. New Mexico Board of Examiners, ${ }^{148}$ unanimously affirmed the New Mexico judgment. Mr. Justice Stewart, writing for eight inembers of the Court, began by disposing easily of the commerce clause claim. Then he turned to more difficult questions under the Communications Act. The field of broadcasting, in the Court's view, did not inherently require national uniformity of regulation in all matters. Thus state law would be displaced by federal law only to the extent there was "such actual conflict between the two schemes of regulation that both cannot stand in the same area, [or] evidence of a congressional design to preempt the field."149 In the issue of the eyeglass price advertising regulation, the Court found neither actual conflict nor preemptive intent.

It was conceded that the Federal Communications Commission held extensive power in "passing upon the fitness of an applicant" to broadcast in "the public interest, convenience and necessity."150 It was also clear that this power might include some consideration of a broadcaster's advertising practices. Nevertheless, to Justice Stewart, "the nature of the regulatory power given to the federal agency convinces us that Congress could not have intended ... to supplant all the detailed state regulation of professional advertising practices, particularly when the grant of power to the Commission was accompanied by no substantive standard other than the 'public interest, convenience and necessity." "151 What the

146 New Mex. Bd. of Examiners in Optometry v. Roberts, 70 N.M. 90, 370 P.2d 811 (1962).

147 N.M. Stat. \& 67-7-13 (1953). Almost 30 other states had similar statutes at the time. See Head v. New Mex. Bd. of Examiners in Optometry, 374 U.S. 424, 426 n.3 (1963). 148374 U.S. 424 (1963).

148 Id. at 430 . The Court here quoted from an earlier decision of the same term, Florida Lime \& Avocado Growers, Inc. v. Paul, 373 U.S. 132, 141 (1963). The Court there found state regulations of the maturity of avocados not to have been preempted or superseded by various federal agricultural marketing provisions.

15048 Stat. 1083 (1934), 47 U.S.C. \& 307(a) (1958).

151374 U.S. at 431. 
Court presumably meant by the "nature of the regulatory power" was the FCC's authority to cancel or revoke broadcast licenses, a drastic sanction quite disproportionate to mimor infractions such as advertising irregularities, and for that reason ineffective in dealing with such matters. ${ }^{152}$ Because of the Commission's apparent inability or disinclination to regulate the practices with which the New Mexico statute was concerned, the Court doubted that "Congress has ousted the States from an area of such fundamentally local concern." Nor was there an actual conflict between the two regulatory schemes: State law in no way impaired the full implementation of the federal regulatory objectives, there being "no specific federal regulations even remotely in conflict with the New Mexico law. ...."153

Mr. Justice Brennan, in a separate opinion, agreed with the Court's conclusion but expressed his own reasons. At the outset he noted that the FCC's regulatory powers were no longer confined to the drastic "death sentence," concededly inappropriate for advertising abuses and other minor infractions. The Communications Act had been amended in 1960 so as to equip the Commission with more appropriate sanctions, including short-term license renewals and the power to exact money "forfeitures" (fines, in effect) for violations insufficient to warrant the termination of a license. ${ }^{154}$ Thus the issue before the Court ought to be framed more precisely than the majority had done.

Moreover, the FCC had "concerned itself with the content of radio advertising almost from the time that federal regulation of commercial broadcasting began."155 Thus the question of federal preemption or supersession could not turn either on any supposed lack of appropriate sanctions or of "any want of authority in the Commission to regulate the subject matter of the New Mexico statute."156 The solution must come instead from a careful application of the criteria which generally deterinine questions of federal preenuption.

152 See Smead, Freedom of Speece by Radio and Television 3, 30 (1959); 2 Socolow, The Law of Radio Broadcasting 1005 (1939); Note, Broadcast Licensee's Past Conduct as a Determinant of the Public Interest, 23 U. PITT. L. REV. 157, 160 (1961). See also the comment of the House Committee on Interstate and Foreign Commerce, H.R. Rep. No. 1800, 86th Cong., 2d Sess. 16 (1960).

153374 U.S. at 432.

$154 \S 503$ (b), added by 74 Stat. 894 (1960), 47 U.S.C. $\$ 503$ (b) (Supp. V, 1964); § 307 (d), added by 74 Stat. 889 (1960), 47 U.S.C. \& 307(d) (Supp. V, 1964). In the 1960 amendments Congress also strengthened the Commission's cease and desist order powers, § 312 (b), added by 74 Stat. 893 (1960), 47 U.S.C. $\S 312$ (b) (Supp. V, 1964). On the scope and nature of these 1960 amendments, see generally Comment, Enforcement Provision of the Communications Act, 18 FED. CoM. B.J. 45 (1963).

155374 U.S. at 437 (concurring opinion).

156 Ibid. 
There was first of all, as Justice Stewart had said, nothing inherent in the nature of broadcasting which required national uniformity of regulation. The second question was one of congressional intent whether the statute or the legislative history revealed a legislative design to occupy the entire field or that part of it involved in the case. In the text and background of the Communications Act Justice Brennan found neither. Congress had in fact manifested at several points its understanding that state law should survive for the most part. The statute containing a saving clause preserving "the remedies now existing at common law or by statute." "157 And by contrast to federal regulation of other communication media, the telephone and telegraph, the supervision of broadcasting was quite shallow. ${ }^{158}$ Finally, there were detailed federal statutes dealing with other broadcasting matters (obscene, indecent or profane language, ${ }^{159}$ fraudulent communications, ${ }^{160}$ deceptive advertising, ${ }^{161}$ rigged quiz shows ${ }^{162}$ and "payola,"163 among others). Such particularity elsewhere suggested rather clearly that Congress had not meant to oust all state power to deal with nondeceptive advertising.

A third criterion of federal preemption had still to be considered: Was there an actual conflict in operation between the state and federal laws? Here again Justice Brennan agreed with the Court's conclusion, but offered narrower and more precise reasons. Unlike the case of political equal-time broadcasts, ${ }^{164}$ in which the Court had already held state law superseded because of conflict with the Communications Act, ${ }^{165}$ there was no conflict here. The purposes of state and federal action in the field were wholly different. Moreover, the FCC had suggested to broadcasters that one measure of responsibility to the "public interest" standard was the degree of comphiance with state and local regulations of commercial advertising. ${ }^{166}$ The National Association of Broadcasters, sensitive to federal-state conflicts, had taken essentially the same position. ${ }^{167}$ Finally, it seemed unkikely as a practical matter that the FCC could

$157 \S 414,48$ Stat. 1099 (1934), 47 U.S.C. § 414 (1958).

158 See United States v. Radio Corp. of America, 358 U.S. 334, 348-49 (1959); FCC v. Sanders Bros. Radio Station, 309 U.S. 470, 474 (1940).

15918 U.S.C. \$ 1464 (1958).

16018 U.S.C. $\$ 1343$ (1958).

16115 U.S.C. $\$ \$ 45,54(\mathrm{~b})$ (1958).

$162 \S 509$, added by 74 Stat. 897 (1960), 47 U.S.C. $\S 509$ (Supp. V, 1964).

$103 \S 508$, added by 74 Stat. 896 (1960), 47 U.S.C. $\$ 508$ (Supp. V, 1964).

164 Required by $\S 315,48$ Stat. 1088 (1934), as amended, 47 U.S.C. $\S 315$ (Supp. V, 1964).

165 Farmers Educ. \& Coop. Union v. WDAY, Inc., 360 U.S. 525 (1959).

166 See Letter of Acting Chairman Paul A. Walker to Senator Edwin C. Johnson, Aug. 11, 1949, 5 Radio Reg. 593, 594.

167 See National Ass'N of Broadcasters, The Televiston Code 14 (8th ed. 1963); National Ass'n of Broadcasters, The Radio Code (9th ed. 1962). 
police minor advertising infractions even if it were disposed to do so. Thus no conflict had been demonstrated and the particular state regulation should be upheld.

The lessons of the Head case for our present inquiry are several. First was the insistence, in which all Justices concurred, that claims of preemption in the broadcasting field would be resolved by particular application of general principles to the precise facts of each case. Equally important was the Court's rejection, also unanimous, of a test proposed by the Solicitor General in a brief as amicus curiae. He had urged reversal on the theory that advertising regulation should be left entirely to the FCC. ${ }^{168}$ A statute of this sort was distinguished from the application of traditional tort and criminal remedies which, in the Solicitor General's view, survived the enactment of the Communications Act even though they might more drastically affect the broadcaster's activities than an injunction against a certain kind of advertising. The Court gave rather short shrift to the "traditional tort and crime" test: "We can find no material difference," said Justice Stewart, "with respect to the less "traditional' statutory violation here involved." 160 The real significance of the Court's rejection of the tort-crime test appears from other parts of both opinions. What was important in determining survival of state court remedies against the broadcaster was clearly not the source of the state's power to regulate. The crucial element, instead, was the practical effect of a particular sanction on the broadcaster and on the whole scheme of federal regulation. Thus some remedies which were not rooted in the tort or criminal law might survive, on basically the same theory that upheld the state's power to curtail eyeglass price advertising. Conversely, certain other remedies which derived from "traditional" tort and criminal law might yield if, on careful examination of their nature and effect, there was evidence either of a congressional intent to displace them or of a conflict with the Commission's activities. This test is surely not simple of application, but it represents a cautious and sensitive approach to a complex problem of interaction between federal and state law.

The picture is complicated by one other case in which the Supreme Court did find state law displaced by the Communications Act. That is the case of the broadcaster's liability for defamation during a broadcast he was compelled to carry under the "equal-time" provision. ${ }^{170}$ This

108 The brief argued at some length that "the state court's injunction intrudes upon the federal scheme," because the application of state regulations like the one at bar might "cause direct and substantial interference with this interstate medium of communication ...." Brief for the United States as Amicus Curiae, pp. 27-34, Head v. Now Mex. Bd. of Examiners in Optometry, 374 U.S. 424 (1963).

169374 U.S. at 431.

$170 \S 315,48$ Stat. 1088 (1934), as amended, 47 U.S.C. $\S 315$ (Supp. V, 1964). 
section of the Act provides that a broadcaster who makes his facilities available to one candidate for a political office must furnish to other candidates for that office broadcasting opportunities which are equal in all respects. The provision was part of the original Communications Act of 1934, and had a predecessor in the Act of 1927.171 But until 1959, when the Court resolved the issue, there had been great uncertainty, in the courts and in the Commission, on two questions: (1) Whether a station had the power to censor material in an equal-time script or speech that was clearly defamatory; ${ }^{172}$ (2) If not, or when the defamation came by way of impromptu remarks, whether the broadcaster could resist hability on the ground that federal law compelled him to carry the broadcast. State courts had resolved these questions differently, ${ }^{173}$ and the Commission had not spoken decisively. ${ }^{174}$ Althougl many state legislatures had conferred a special immunity for equal-time broadcasts, liability remained a distinct threat in other states, including North Dakota, whence came the 1959 case.

In Farmers Educational and Cooperative Union v. WDAY, ${ }^{175}$ a sharply divided Supreme Court agreed with the North Dakota court that federal law implicitly required an immunity for the broadcaster wlio im-

171 Federal Radio Act, \& 18, 44 Stat. 1170 (1927).

172 See, e.g., Friedenthal \& Medalie, The Impact of Federal Regulation on Political Broaddasting: Section 315 of the Communications Act, 72 HARv. L. REv. 445, 478-80 (1959); Comment, 1 U. FLA. L. Rev. 343, 355 (1948); Note, 32 So. CaL. I. Rev. 71 (1958); cf. Snyder, Liability of Station Owners for Defamatory Statements Made by Political Candidates, 39 VA. L. REv. 303, 313-14 (1953). Apparently the practice of the broadcasting industry during these uncertain years was to suggest changes to the speaker where defamation was feared; apparently the speaker usually complied with the suggestion. But if lhe did not, the broadcaster could not avoid carrying the speech, however clearly it might be a source of potential tort liability. See Note, Broadcaster's Immunity From Liability for Political Defanation, 48 Geo. L.J. 544, 556 (1960). If the station on its own deleted material in the script which it believed to be clearly defamatory, that raised further problems on which the law was uncertain. See De Grazia, Equal Political Defamation for All: Section 315 of the Federal Communications Act, 20 GEo. WASE. L. REv. 706, 720 (1952). 173 Compare, e.g., Daniell v. Voice of New Hampshire, 10 Radio REG. 2045 (N.H. Super. Ct. 1954); Sorensen v. Wood, 123 Neb. 348, 243 N.W. 82 (1932), with, e.g., Lamb v. Sutton, 164 F. Supp. 928 (M.D. Tenn. 1958), aff'd, 274 F.2d 705 (6th Cir. 1960); Josephson v. Knickerbocker Broadcasting Co., 179 Misc. 787, 38 N.Y.S.2d 985 (Sup. Ct. 1942); Clarles Parker Co. v. Silver City Crystal Co., 142 Conn. 605, 116 A.2d 440 (1955).

174 The Commission did not speak clearly on the question until 1948. See In re Port Huron Broadcasting Co., 12 F.C.C. 1069 (1948). It suggested there in a strong dictum that the broadcaster would not be hable for carrying a program required to be carried under $\$ 315$. That dictum was sharply criticized by at least one court, although the statement was never judicially reviewed. Houston Post Co. v. United States, 79 F. Supp. 199 (S.D. Tex. 1948). Uncertainty persisted in the wake of the Port Huron declaration, and the FCC did little to clarify the Port Huron doctrine during the next few years. See Note, 4 Baylor I. Rev. 516 (1952); Note, 61 YaLE L.J. 87 (1952).

175360 U.S. 525 (1959). 
voluntarily carried defamatory political matter. Having decided that the statute permitted no censorship of the script, even where it obviously contained actionable material, the Court turned to the heart of the case. Although the legislative history was silent, and might even have suggested that Congress meant to leave state law intact, a majority of the Court could not "reach a result which seems so in conflict with traditional concepts of fairness."176 Broadcasters might, of course, insure against hability for pohtical defamation, or avoid the equal-time law altogether by carrying no candidate's speeches. But the whole purpose of that law, "to facilitate political debate over radio and television," would be frustrated if fear of heavy damages forced stations to sliun political involvement. ${ }^{177}$ Thus, to the majority, Congress must have meant to confer an inmunity in order to make the equal-time provision effective.

This judgment with respect to legislative intent made it unnecessary, of course, to consider the effect of the obvious practical conflict between federal and state law. The four dissenters, who disagreed on the matter of congressional intent, did reacl that question but minimized the conflict. The dissenters, beginning with the doubtful premise that a station could not be hable without proof of intent to defame, ${ }^{178}$ suggested that the North Dakota courts might well have found no liability under state law, quite apart from the intent of Congress. But even if that were not so, said Justice Frankfurter, "there is not that conflict between federal and state law whicl justifies displacement of state power."170 The effect of state libel suits was not, as the majority had suggested, to prohibit broadcasters "from airing speeches by political candidates," but only to "make such broadcasts potentially less profitable" even if insurance and indemnification were available. ${ }^{180}$ If there was something unfair about saddling the broadcaster with liability he could not avoid, that was no more inequitable than turning away an imjured plaintiff without redress for no fault on his part. Finally, the dissenters would leave the immunity question up to Congress, which had repeatedly failed to act. Against this background, it was not for the Court to do what the legislators would not do.

These, then, are the two cases that bear most closely upon the ques-

176 Id. at 533 .

177 Id. at 534 .

${ }^{178} \mathrm{Id}$. at 542 (dissenting opinion). "It is to be noted initially that since defamation is generally regarded as an intentional tort, it is a solid likelihood that the North Dakota courts would conclude that WDAY's compelled broadcast of Townley's speech lacked the necessary intent to communicate the defamation, and that therefore WDAY's conduct was not tortious, or, if prima facie tortious, that WDAY was privileged."

179 Id. at 544 (dissenting opinion).

180 Ibid. 
tion of federal preemption of state tort suits against the broadcaster. Our present inquiry begins where WDAY left off. The central question is whether the courts ought to recognize any privilege or immunity under federal law where the offending broadcast is not strictly required by the Communications Act. There is nothing in WDAY which precludes an extension of its holding; the majority nowhere indicated that a conflict between federal and state law might not be found even without the presumed Congressional intent which had decided that case in favor of immunity. ${ }^{181}$ It is appropriate, then, to explore some contexts in which such conflict may exist, and then to consider whether any of these lesser conflicts would justify the partial displacement of state law.

\section{The FCC and State Tort Law Violations}

A radio or television broadcaster receives his license on condition that he serve the "public interest, convenience and necessity."182 Failure to do so may result in loss of the license at the end of its term. ${ }^{183}$ Serious departures from this standard, or persistent violations of the major commands of the statute, may even result in the revocation of a license before it expires. ${ }^{184}$ These sanctions are obviously severe, and few broadcasters lose their licenses. Since its establishinent, the FCC has regulated more effectively "by raised eyebrow" than by use of the "death sentence."185

181 Even after the decision of the WDAY case, many issues arising under $\S 315$ remained to be considered and debated. See Harum, Federal Occupation of Political Defamation, 49 A.B.A.J. 1096 (1963); Erbst, Equal Time for Candidates: Fairness or Frustration?, 34 So. CaL. L. Rev. 190 (1961); Comment, Should Political Broadcasting Be Fair or Equal?, 30 GEO. WASH. L. REv. 63 (1961). In addition, the section was amended the following year because of a very strict interpretation announced and adhered to by the FCC. The amendment was the so-called "news clip" provision which exempted from the equal-time mandate certain incidental appearances of pohtical candidates on newscasts, news documentaries and interviews, 73 Stat. 557 (1959), 47 U.S.C. \$ 315(a) (Supp. V, 1964). See Note, Radio and Television Appearances of Candidates for Office: Amended Section 315 of the Commenications Act, 69 YaLE L.J. 805 (1960); 73 Harv. L. REv. 794 (1960). 182 § 307 (a), 48 Stat. 1083 (1934), 47 U.S.C. \& 307 (a) (1958).

183 See KWK Radio, Inc., v. FCC, 337 F.2d 540 (D.C. Cir. 1964); Robinson v. FCC, 334 F.2d 534 (D.C. Cir. 1964) ; Trinity Methodist Churcl, South v. Federal Radio Comm'n, 62 F.2d 850 (D.C. Cir. 1932); KFKB Broadcasting Ass'n, Inc. v. Federal Radio Comm'n, 47 F.2d 671 (D.C. Cir. 1931).

184 The FCC has power to revoke as well as to refuse renewal of a broadcast hicense, 48 Stat. 1086 (1934), as amended, 47 U.S.C. $\$ 312$ (a) (1958).

185 Note, Broadcast Licensee's Past Conduct as a Determinant of the Public Interest, 23 U. PITT. L. REv. 15\%, 170 (1961). One observer notes that "the licensing power of the FCC hangs like a Damocles' sword over broadcasting . . . "Schwartz, Antitrust and the FCC: The Problem of Network Dominance, 107 U. PA. REv. 753, 769 (1959). Thus informal warnings and suggestions to broadcasters are usually sufficient to ensure compliance, see Wold, Adamnistratrve Law: The Inrorarax Process 139 (1963); and speeches and informal statements by individual commissioners have a profound effect on the behavior of the industry, see Note, Television Programming, Communication Research, and the 
Since 1960 the Commission has been able to police lesser infractions with less drastic sanctions of cease and desist orders, short-term license renewals, and of imposition of money forfeitures. ${ }^{180}$ These sanctions have been imposed occasionally for improper programming as well as for the more frequent technical violations. ${ }^{\mathbf{1 8 7}}$

Under the general rubric of "public interest" the FCC undoubtedly has power to consider flagrant violations of state tort law in appraising the performance of a licensee. Indeed, even before the present Communications Act at least one license was revoked primarily because of repeated and extreme instances of defamation directed both at groups and at individuals. ${ }^{188}$ Since that time, however, the Commission appears only once to have taken defamation into account in a licensing proceeding, and only indirectly at that. ${ }^{189}$ So while the Commission undoubtedly

FCC, 23 U. PrTT. L. REV. 993, 996 (1962). Another observer notes that "indirect means, such as letters of advice and statements of policy are more common" than formal sanctions where broadcasting practices are thought by the Commission to be contrary to the public interest. Note, Regulation of Program Content by the FCC, 77 HaRv. L. Rev. 701, 703 (1964).

186 See statutes cited notes 159-63 supra.

187 See proceedings reported in 28 FCC ANN. REP. 46-48 (1962); 29 FCC ANN. REP. 49-51 (1963); 30 FCC ANN. REP. 54-55 (1964).

188 Trinity Methodist Church, South v. Federal Radio Comm'n, 62 F.2d 850 (D.C. Cir. 1932). See In re Shuler, 210 Cal. 377, 292 Pac. 481 (1930), involving contempt proceedings against the broadcaster.

189 In Bellingham Pub. Co., 6 F.C.C. 31, 32 (1948), the Commission denied the application of a newspaper publisher for a broadcast station license. One of the grounds for the hearing examiner's rejection of the application, later affirmed by the full Commission, was the presumably defamatory nature of some editorials the publisher had injected into local political controversies. The examiner found that such publications contained "numerous articles reflecting upon the honesty and integrity of public officials and upon the inorals and private hives of the citizens of Bellingham"; and that such material was a "source of discord and dissension inimical to the general welfare of the community." Before the Commission the apphicant claimed that judgment of such material was more appropriate for the courts than for an administrative agency, but the Commission found the evidence quite relevant to the broadcast application. "That course if extended to radio broadcast service would bave a definite relation to the public interest . . . " See also Bellingham Broadcasting Co., 8 F.C.C. 159, 172 (1940).

There are other cases in which some consideration appears to have been given to possibly defamatory conduct on the part of broadcast hicensees or applicants for hicenses. For example, in Independent Broadcasting Co. v. FCC, 193 F.2d 900, 902 (D.C. Cir. 1951), cert. denied, 344 U.S. 837 (1952), the court of appeals affirmed the Commission's demial of two license applications resting partly on the grounds of misrepresentation and failure to make full disclosure concerning the applicant's "behavior." The court observed, in finding support for the Commission's judgment on this point, that the record "contained information showing not only that ... [the applicant] had been intemperate in his writings, sermons and broadcasts, but that he was an expert in vituperation and vilification."

Recently the Commission granted the Broadcast Bureau's request for an evidentiary hearing on applications for a television channel in Oregon. In passing, it reported the Bureau's serious concern that one of the applicants had engaged in persistent defamation during editorial broadcasts, but declined to pass on the Bureau's charge in the absence 
has the power to police defamation, the fact is it has seldom used that power. ${ }^{100}$ On the other hand, in time the new intermediate sanctions contamed in the 1960 amendments may revive the Commission's interest in defamatory broadcasting, ${ }^{101}$ an interest probably previously chilled because of the severity of the remedy.

of more specific allegations. By reference to the Oregon statutes governing libel and slander, however, the Commission suggested that proof of such allegations would be highly relevant to the apphicant's qualifications. However, in the absence of "a showing as to factual inaccuracy in the broadcasts, the question of whether ... [the applicant] showed a wanton disregard of the facts is not presented." In re Application of Willammette-Land Television, Inc., No. 13748, FCC, Feb. 19, 1962.

Recently the FCC has been considering numerous objections to the transfer of a Pennsylvania radio station to a religious group headed by the controversial Reverend CarI McIntire. Various protesting groups have charged that Dr. McIntire's attacks on certain religious groups, his strong views on the United Nations and civil rights, and the like, make him unfit to control a broadcasting outlet. The FCC entertained arguments by various religious groups, labor organizations, and such civil rights and civil liberties groups as the NAACP and the Anti-Defamation League of B'nai B'rith. See FOI Digest, Jan.-Feb. 1965 , p. 6. But the Commission has recently concluded that the complaints are insuficient, in view of the apphicant's expressions of good intentions and promises to serve the public interest. Thus the Commission dechined to deny an initial license on the basis of these charges. In re Apphication of Borst, No. 65-207, FCC, March 19, 1965.

Finally, the FCC has issued at least one stern warning to a broadcaster engaged in activities that might be defamatory and which did in fact eventually give rise to several defamation suits. Early in 1961 the Commission received several complaints about certain episodes of "The Untouchables." For example, the Director of the Federal Bureau of Prisons objected that the program misled viewers by purporting to recreate the facts of the transfer of Al Capone from Atlanta to Alcatraz, when in fact most of the episode was fictional. In response to these complaints the Commission admonished the American Broadcasting Co. to be wary of creating "erroneous inpressions with respect to programming represented as being factual in character." Such misimpressions might, suggested the Commission, violate the "public interest" standard. "This is doubly true," the letter added, "where the result is to damage the reputations of identifiable individuals or groups." FCC Public Notice-B, Rep. No. 3919, Sept. 28, 1961. Apparently nothing further came of these complaints at the administrative level, but the very episodes to which the letter referred gave rise to the successful defamation suit in American Broadcasting-Paramount Theatres, Inc. v. Sinpson, 106 Ga. App. 230, 126 S.E.2d 873 (1962).

190 For suggestions that the FCC does have such power, see Sumunit Hotel Co. v. NBC, 336 Pa. 182, 202, \& A.2d 302, 311 (1939); Caldwell, Legal Restrictions on the Contents of Broadcast Programs, 9 AIR L. Rev. 229, 248 (1938); Graham, Defamation and Radio, 12 WaSH. L. REv. 282, 292-93 (1937); Haley, The Law on Radio Programs, 5 Geo. Wash. L. Rev. 157, 189-90 (1937); 47 Mich. L. Rev. 722, 723 (1949); I J. Radio LaW 362, 367 (1931).

101 There has been a recent resurgence of interest on the part of the Commission, and of its observers and critics, in the subject of control or regulation of program content. Among the important recent cases are KWK Radio, Inc., 34 F.C.C. 1039 (1963), aff'd per curiam, 337 F.2d 540 (D.C. Cir. 1964); Palmetto Broadcasting Co., 34 F.C.C. 101 (1963), afj'd sub nom. Robinson v. FCC, 334 F.2d 534 (D.C. Cir. 1964); Immaculate Conception Church of Los Angeles v. FCC, 320 F.2d 795 (D.C. Cir. 1963); In re Application of Pacifica Foundation, No. 45386, FCC, Jan. 22, 1964. Many materials and arguments in support of the FCC's authority are collected in FCC, Applicability of the Fairness Doctrine in the Handling of Controversial Issues of Public Importance, 29 FED. REG. 10415 (1964); 
The mere fact that the FCC can and does consider defamation in license proceedings would not, of course, displace state law. As Mr. Justice Brennan pointed out in the Head case, the Commission has similar powers with respect to the advertising practices proscribed by the New Mexico law, but that alone was no reason for preemption. Unless the intent of Congress was to preempt, there must be an actual conflict; the effect of the state law must be to impede seriously the work of the federal agency. So the present question is whether the state law of defamation or of invasion of privacy could pose such a conflict.

\section{The Broadcaster's Duty to Engage in Controversy}

The answer to this question requires a consideration of the obligations the broadcaster incurs when he promises to serve the public interest. One of his most important responsibilities, long recognized and vigorously enforced by the $F C C$, is to present a fair and balanced survey of important public issues. ${ }^{102}$ That means more than simply carrying regular news reports, and panel discussions and interviews when he chooses. It means at least that the broadcaster may not cut his station off from discussion of the pressing issues of the day. Moreover, in presenting those issues, he must offer both, or all, points of view in rough balance. $^{193}$ Thus the broadcaster must obviously carry some material he may disagree with and might avoid if the choice were completely his, or if he were running a newspaper or magazine rather than a regu-

Rosenblum, Authority of the Federal Communications Commission, in FreEdon \& REsponSIBIIITY IN BROADCASTING 96 (Coons ed. 1961). But the whole question of just where the FCC stands on the general issue of network program control is still very much in doubt. See Broadcasting, March 8, 1965, p. 70.

102 See generally FCC, Applicability of the Fairness Doctrine to the Handling of Controversial Issues of Public Importance, 29 FEd. REg. 10415 (1964); SMAEAd, FreEdom OF SPEECH BY RADIO AND TELEVISTON 45-63 (1959).

183 Originally the Commission held that broadcasters could not editorialize at all, Mayflower Broadcasting Corp., 8 F.C.C. 333, 339-40 (1941). Eight years later the Commission modifed this view and held that editorializing was permissible, so long as broadcasters gave fair treatment to all controversial issues. See "Editorializing by Broadcast Licensees," 13 F.C.C. 1246, 1253 (1949). Recently the equal-time law has been amended so as to inpose upon every broadcaster an obligation "to afford reasonable opportunity for the discussion of conflicting views on issues of public importance." 73 Stat. 557 (1959), 47 U.S.C. $\S 315(\mathrm{a})$ (Supp. V, 1964). There is some question whether this 1959 proviso simply codifies a preexisting obligation of the broadcaster, or creates a netw substantive obligation. See Note, 69 YALE L.J. 805, 812-15 (1960). On the development of this doctrine through its earlier stages, see Comment, Mayflower Rule-Gone But Not Forgotten, 35 Cornerr L.Q. 574 (1950); Note, Radio Editorials and the Mayflower Doctrine, 48 Coutur. L. Rev. 785 (1948); Note, The Mayflower Doctrine Scuttled, 59 Yale L.J. 759 (1950). For the interesting and iniportant views of the National Association of Broadcasters on the application of the fairness doctrine to the broadcasting of controversial issues, see NArtonaL Ass's of Broadcasters, Polttical Broadcast Catechism 15-16, 28 (4th ed., rev. 1964). 
lated and licensed facility. He may even be obligated to carry material he fears will involve him in lawsuits. ${ }^{194}$

Two specific recent examples may illustrate the general point. Political broadcasting seems a good starting point. The equal-time law only requires the broadcaster to provide time to a candidate when the station has already allotted air time to an opponent. Thus it lias been suggested that the broadcaster could avoid political defamation by staying out of campaigns altogether. ${ }^{105}$ The Commission, however, lias more than once suggested that a broadcaster jeopardizes his license by hiding from politics. ${ }^{106}$ Consideration of the public interest necessarily involves some attention to political issues and campaigns. It is really no answer, therefore, to say that the broadcaster is legally obligated only to carry the speech of the second and successive candidates, but not that of the first candidate who comes to him. The obligation is of a different degree, and is of course not specifically enforceable by a rejected candidate. ${ }^{197}$ But it is nonetheless an obligation which federal regulation imposes to some degree on every broadcaster.

Another current example will underscore the legal dilemma in which

194 The FCC has recently suggested that there is an affirmative obligation to seek out and discuss controversial issues as they may arise, Rollins Broadcasting, Inc., 34 F.C.C. 1, 81-82 (1963). See Note, 77 HaRv. L. Rev. 701, 710 (1964).

195 See, e.g., Friedenthal \& Medalie, supra note 172, at 476-7\%. There is some question about the meaning that should be given to a sentence in $\S 315$ : "No obligation is imposed upon any licensee to allow the use of its station by any such candidate." Arguably this provision, without more, would absolve the broadcaster from any responsibility to make his facilities available for political activities.

106 See, e.g., Rollins Broadcasting, Inc., 34 F.C.C. 1, $82-83$ (1963) ; cf. United Broadcasting Co. (WHKC), 10 F.C.C. 515 (1945); In re Rainey, 3 Radio Reg. 737 (F.C.C. 1947): See also Friedenthal \& Medalie, supra note 172 , at $477-78$ \& n.198 (reporting a questionnaire in which $77 \%$ of broadcasters surveyed felt they should have absolute discretion to refuse any part in political broadcasting); Snyder, Liability of Station Owners for Defamatory Statements Made by Political Candidates, 39 VA. L. REv. 303, 307 (1953); Developments in the Law-Defamation, 69 Harv. L. Rev. 875, 909-10 (1956)1; Note, Broadcaster's Immunity From Liability for Political Defamation, 48 Geo. L.J. 544, 548 (1960); Note, 69 Yare L.J. 805, 806 n.7 (1960); 24 So. CaI. L. Rev. 216, 217 (1951); 2 OKIA. L. REv. 257, 258 (1949).

107 One court has recently held that $\S 315$ does not create a private civil remedy in favor of one who has been allegedly wronged by a broadcaster's refusal of equal time for a political broadcast. Daly v. CBS, 309 F.2d 83 (7th Cir. 1962). Several state courts have enforced contracts obligating a broadcaster to carry political speeches, without reference to the possible impact of federal regulation, e.g., Rose v. Brown, 186 Misc. 553, 58 N.Y.S.2d 654 (Sup. Ct. 1945); but cf. Vohva v. WCBD Inc., 313 Ill. App. 177, 39 N.E.2d 685 (1942), in which the court refused to enjoin a station's insistence on a 48-hour advance submission of scripts for political broadcasts. The remedy of a candidate who has been refused equal time is, therefore, resort to the FCC, which may then exercise informal sanctions and if those prove ineffective may turn to more formal niethods of enforcement. See Friedenthal \& Medalie, supra note 172 , at $488-89$, noting that formal means of enforcement may prove unsatisfactory because of the expense and delay they are likely to entail. 
the "public service" obligation may place the broadcaster. The FCC has just begun to examine the way in which broadcasters have responded to the civil rights controversy. The licenses of several stations in Mississippi have recently come up for renewal. ${ }^{108}$ Earlier the Commission warned one of these stations that it miglit be acting contrary to public interest in denying time to a Negro candidate for local office even thougl the equal-time law clearly did not require such time. ${ }^{190} \mathrm{Now}$, the renewal of these licenses has been opposed by various political, civic and labor groups because of the stations' persistent refusal to discuss the civil rights question at all, or at least to present it fairly when it was discussed. The disposition of this case clearly indicates that the commission will closely examine and carefully consider such charges in the future. ${ }^{200}$

These and other recent cases indicate that the broadcaster is increasingly obligated to carry material that may be offensive to him and inflammatory to the community. The chances that a jury in Mississippi will find something defamatory in the speech of a Negro candidate or in a frank panel discussion of civil rights seem greater than in the North and West. ${ }^{201}$ Thus a vigorous application of the "public interest" criteria may well force some broadcasters either to jeopardize their licenses by

198 As early as the spring of 1964 , complaints were made that the two television stations in Jackson, Mississippi had failed fairly and evenly to present and discuss issues relating to civil rights. At this time it was reported that eight Mississippi broadcasters were under investigation for suspected violations of the fairness doctrine in their coverage of the riots at the University of Mississippi during the admission of INegro student James Meredith. See Broadcasting, April 20, 1964, p. 44. The Mississippi AFL-CIO made similar charges later in the spring, and formally opposed the renewal of one of the Jackson licenses. Broadcasting, June 8,1964 , p. 66 .

100 Lamar Life Ins. Co., 18 Radio Reg. 683 (F.C.C. 1959), discussed in FCC, Applicability of the Fairness Doctrine in the Handling of Controversial Isstes of Public Importance, 29 FED. REG. 10415, 10418 (1964); Note, 77 HARv. L. REv. 701, 710 (1964). For earlier suggestions that broadcast licensees incurred some obligation to present civil rights issues with particular fairness and balance, see Herbert Muschel, 33 F.C.C. 37, 40 (1962); New Broadcasting Co. (WLIB), 6 Radio REg. 258 (F.C.C. 1950).

200 On May 20, 1965, the FCC renewed for a one year probationary term the license of a Jackson, Mississippi television station that had been charged with violating the fairness doctrine in its coverage of civil rights issues. The American Civil Liberties Union, the American Federation of Labor and Congress of Industrial Organizations, and the United Church of Christ had all urged the Commission to deny the station's application for license renewal. See ACLU News Release, March 24, 1965; Broadcasting, March 1, 1965, p. 57. Among other practices, the station was charged with having cut off part or all of certain programs that advocated racial desegregation. Four members of the Commission concluded that a one-year renewal and a formal warning to the station would suffice. Two members of the Commission, inciuding Chairman Henry, would have set the case down for a formal hearing leading to possible cancellation of the hicense. See N.Y. Times, May 21, 1965, p. 1, col. 2; p. 36, col. 4.

201 For a vivid description of the position of jeopardy in which the southern press may be placed by speaking out boldly on questions of civil rights, see Lyons, Liebling, Libel, and the Press, The Atlantic, May 1964, p. 43, at 46-47. 
avoiding controversiality or risk heavy tort liability by engaging in controversy. This dilemma suggests an important basis for the extension of the federal immunity first recognized in $W D A Y$.

\section{Bases of Immunity Under Federal Law}

The law of broadcasting does not yet recognize any immunity beyond the $W D A Y$ decision, and extension of that decision has not even been considered. There has, however, been some litigation in other federally regulated fields that suggests a basis for such an extension. One such suggestive analogy comes from the labor field. Several courts have recently held that the federal labor laws displace any recovery under state defamation law for false statements made by a union official about his employer during, and related to, a labor dispute over which the NLRB has jurisdiction. ${ }^{202}$ Although the courts recognize the inadequacy of federal administrative relief against such defamation, they have nonetheless concluded that the Supreme Court's decision in San Diego Building Trades Council v. Garmon ${ }^{203}$ leaves no room for state law where the union's statements might constitute an unfair labor practice, even though the Board has refused to act. ${ }^{204}$ But the very breadth of the Garmon test suggests why it does not apply to other regulated sectors such as broadcasting. Federal preemption has gone much further in labor relations than elsewhere. The Garmon doctrine finds no counterpart in broadcasting. ${ }^{205}$ Thus, on analysis, this analogy provides a weak basis for the extension of WDAY.

Much more apposite is the developing law concerning the liability of airlines for damage resulting from noise and vibration near jet airports. Several courts have refused, for example, to permit state law to enjoin takeoffs and landings, even where the resulting noise may be deafening and make hife intolerable adjacent to the flight-paths. ${ }^{206}$ Build-

202 See Linn v. United Plant Guard Workers Local 114, 337 F.2d 68 (6th Cir. 1964); Blum v. International Ass'n of Machinists, 42 N.J. 389, 201 A.2d 46 (1964); Schnell Tool \& Die Corp. v. United Steelworkers, 200 N.E.2d 727 (Ohio C.P. 1962). But see Brantley v. Devereaux, 237 F. Supp. 156 (E.D.S.C. 1965). See also 65 ColoM. L. REv. 345 (1965).

203359 U.S. 236 (1959). The Sixth Circuit also relied upon the later Supreme Court cases of Local 100, United Ass'n of Journeymen \& Apprentices v. Borden, 373 U.S. 690 (1963), and Local 207, Internat'l Ass'n of Bridge Workers v. Perko, 373 U.S. 701 (1963).

204 The Sixth Circuit concluded that "if a Regional Director's refusal to issue a complaint [against the defamation] is sustained by the Board's General Counsel as happened in this case, the hbelled individual is at the end of the remedial road." Linn v. Plant Guard Workers Local 114, 337 F.2d 68, 72 (6th Cir. 1964).

205 See Head v. New Mexico Bd. of Examiners in Optometry, 374 U.S. 424, 442-47 (1963) (concurring opinion); Note, State Regulation of Radio and Television, 73 Harv. L. REV. 386, 388-89 (1959).

206 Allegheny Airlines v. Village of Cedarhurst, 238 F.2d 812 (2d Cir. 1956); City of Newark v. Eastern Airlines, 159 F. Supp. 750 (D.N.J. 1958) (declining the injunction 
ing from these cases it has been argued that the airlines should be wholly immune from civil damage suits for noise and vibration losses, although the airports would presumably remain liable. ${ }^{207}$ No court has yet ruled directly on this contention. ${ }^{208}$

The premise of this argument, however, applies imperfectly to broadcasting. The conflict in the air noise context arises because the flight paths are prescribed in detail by the Federal Aviation Administration, with safety considerations paramount. ${ }^{209}$ Federal law would clearly be flouted if a state court could order planes to land or take off on paths other than those prescribed by the FAA, even if no federal agency had specifically found the alternative routes to be less safe. ${ }^{210}$ So the injunctive cases are relatively easy, as would be the case of a state court order purporting to enjoin a political speech which the equal-time law compels a broadcaster to carry.

The question of the civil damage suit against the airhne is harder, however, and the result remains uncertain until such a case arises. Awarding damages would not, of course, actually prevent the airline from serving the community. It would only, to paraphrase Mr. Justice Frankfurter's WDAY dissent, make the airline's operations "potentially less profitable" (or unprofitable). ${ }^{211}$ Yet there are strong reasons both in terms of the demands of federal regulation and in the balance of public interests which might well warrant a federal immunity for aircraft compelled to fly in pre-determined paths.

on grounds of $\mathrm{CAB}$ primary jurisdiction); Loma Portal Civic Club v. American Airlines,

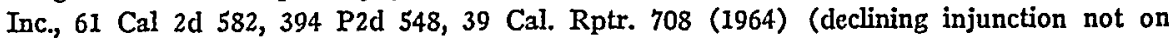
grounds of federal preemption but on balance of interests, including strong interest in comphance with federal safety regulations governing flight-paths). Cf. Jankovich v. Indiana Toll Road Comm'n, 379: U.S. 487, 493-95 (1965), finding no conflict with the Federal Aviation Act in a state court decision awarding compensation for an alleged appropriation of airspace rights of a toll road adjacent to an airport.

207 See Note, Airplane Noise: Problem in Tort Law and Federalism, 74 Harv. L. REv. 1581, 1594-96 (1961); Brief of Allegheny Airlines as Amicus Curiae, pp. 8-18, Griggs v. Allegheny County, 369 U.S. 84 (1962).

208 The $C A B$ presented this position in a brief as amcicus curiae in Gardner v. Allegheny County, $382 \mathrm{~Pa} .88,114$ A.2d 491 (1955), but the question was not reached in that case nor has it been reached in any subsequent decision. See Note, 74 HARv. L. REV. 1581, 1594 n.100 (1961)h In the most recent case involving these issues, the California Supreme Court expressly reserved the question of the possible effect upon a private damage suit of its refusal to enjoin allegedly offensive and injurious overflights. See Loma Portal Civic Club v. American Airlines, Inc., 61 Cal. 2d 582, 590-91, 394 P.2d 548, 554, 39 Cal. Rptr. 708, 714 (1964).

200 See Note, 74 Harv. L. Rev. 1581, 1595-96 (1961).

210 See Allegheny Airlines, Inc. v. Village of Cedarlhurst, 238 F.2d 812, 815 (2d Cir. 1956).

211 Farmers Educ. \& Coop. Union v. WDAY, Inc., 360 U.S. 525, 544 (1959) (dissenting opinion). 
Whatever immunity these factors may confer upon the airlines, however, they may be inapposite for the broadcaster who is effectively compelled to carry controversial matter. Both the broadcaster and the airline may presumably obtain insurance, but the airline has no equivalent to the broadcaster's option of indemnity from the speaker or the sponsor. There is no other party who is either more clearly at fault or better able to bear the loss. More important is the broadcaster's ability to pass on his losses by raising his advertising rates at will; the airline's rates, by contrast, are subject to close and constant $\mathrm{CAB}$ scrutiny. ${ }^{212}$ Indeed, the radio and television broadcaster enjoys almost complete freedoni with respect to the setting of rates and other ternis and conditions of business; he is in this respect much freer than the other media regulated by the FCC, telephones and telegraphs, whose rates are under constant scrutiny. ${ }^{213}$ While this difference does not void the airline analogy, it does suggest that a stronger case nuust be made for the broadcaster's immunity under a similar theory.

There are other factors that argue agamst such an immunity for radio and television. For one, legislative history shows that Congress has many times considered and rejected proposals for such an immunity, at least with respect to equal-tine political broadcasts. ${ }^{214}$ Of course legislative inaction did not deter the Court in $W D A Y$ from taking the step Congress declined to take, but this legislative context should at least make the courts cautious in extending the immunity beyond the $W D A Y$ situation. It is also relevant that the Communications Act contains a comprehensive saving clause: "Nothing in this Act contained

212 Federal Aviation Act, $\S \S 403,404,72$ Stat. 758-60 (1958), as amended, 49 U.S.C. $\S 1373$ (Supp. V, 1964), § 1374 (1958).

213 The principal differences arise because telegraphs and telephones are considered common carriers, while broadcasters are not. See United States v. Radio Corp. of America, 358 U.S. 334, 348-49 (1959); FCC v. Sanders Bros. Radio Station, 309 U.S. 470, 474 (1940).

214 There were strong attempts to incorporate such a provision in the Federal Radio Act of 1926. As the original equal-time provision of that law passed the Senate, it included a guarantee that a broadcaster compelled to carry a political speech "shall not be liable to criminal or civil action by reason of any uncensored utterances thus broadcast." 67 Cong. Rec. 12502, 12505 (1926). Eventually the immunity proviso was removed, however, either because of doubts about its constitutionality or because of a conviction or assumption that no state would inpose such a liability upon a broadcaster anyway. See Memorandum for The United States as Amicus Curiae, pp. 18-19, Farmers Educ. \& Coop. Union v. WDAY, Inc., 360 U.S. 525 (1959). Many subsequent attempts were made to amend such an immumity into the statute. See Petition for Writ of Certiorari, pp. 17-21, Farmers Educ. \& Coop. Umon v. WDAY, Inc., supra (listing and brief description of all pertinent proposals from 1927-1955). See also Donnelly, Defamation by Radio: $A$ Reconsideration, 34 Iowa L. Rev. 12, 38-40 (1948); De Grazia, Equal Political Defamation for All: Section 315 of the Federal Communications Act, 20 GEo. WASE. L. REv. 706, 712 \& $\mathrm{n} .40$ (1952). 
shall in any way abridge or alter the remedies now existing at common law or by statute, but the provisions of this Act are in addition to such remedies." ${ }^{215}$ The Aviation Act contains an identical saving clause, ${ }^{210}$ but other regulatory statutes are less generous to the survival of preexisting remedies.

A further factor which militates against preemption is the FCC's inability to award any form of relief to a private party injured by defamation. While regulatory sanctions might be invoked against a persistent defamer, there is even doubt whether a single defamatory broadcast would give grounds to invoke the administrative machinery against a broadcaster. Moreover, the Commission may award damages only on complaints against "common carriers," a category which does not include hicensed broadcasters. Thus the inability of the regulatory agency to redress private grievances further suggests the intended survival of remedies apart from the statute. ${ }^{217}$

On the other hand, the argument may prove too much. Federal preemption would abrogate only a claim against the broadcaster, so that the other parties responsible for the defamation would remain liable. Thus the plaintiff might not be injured by the loss of one possible defendant, or at least no more than if the broadcaster turned out to be judgment proof. This contention is not persuasive, however, for several reasons. First, the broadcaster is the one party in the picture who is least likely to be judgment-proof; the FCC's rigorous control over the financial responsibility of licensees is a good reason why this defendant ought not to be taken away. ${ }^{218}$ Second, whatever his financial responsibility, the broadcaster is the party most likely to have, and best able to obtain insurance against defamation liability. Third, although the speaker is always theoretically hable, he may often be difficult even to identify, ${ }^{219}$ or he may be outside the jurisdiction of the courts of the plaintiff's state, or he may be judgment-proof even if he is identified and served in the state. ${ }^{220}$ Finally, the liability of the other possible defendants, the producer, the advertising agency, the sponsor and others is uncertain, not only because of doubts about jurisdiction and

$215 \S 414,48$ Stat. 1099 (1934), 47 U.S.C. § 414 (1958).

$210 \S 1106,72$ Stat. 798 (1958), 49 U.S.C. $\$ 1506$ (1958).

217 Cf. Wills v. TWA, 200 F. Supp. 360, 364-65 (S.D. Cal. 1961).

218 See $\S 319$ (a) $h 48$ Stat. 1089 (1934), as amended, 47 U.S.C. $\S 319$ (a) (Supp. V, 1964). Financial qualifications have been considered, e.g., Orange Belt Telecasters, 9 RAdro

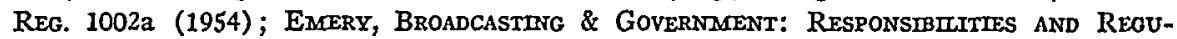
IATIONS 160-61 (1961).

218 See 1 J. Radio Law 362, 365 (1931).

220 Compare Haley, The Law on Radio Programs, 5 Geo. Wase. L. Rev. 157, 196 (1937), with Vold, Defamatory Interpolations in Radio Broadcasts, 88 U. PA. L. REv. 249, 266 n.49 (1940). 
venue, but also because the law respecting their liability is many years behind that of the broadcaster's liability. Thus there seems no adequate substitute for the broadcaster as the logical defendant. For all these reasons it seems unlikely that courts will confer upon the broadcaster a complete immunity from state tort law beyond that already recognized in the WDAY case.

\section{Partial Federal Immunity for the Broadcaster}

The failure to find a legal justification for complete immunity does not dispose of the question. It may be possible to reconcile the interests of injured plaintiffs with those of the broadcaster by recognizing certain limited or partial immunities where some relief from state law is required by the sclieme of federal regulation.

Several such situations come to mind. Recall, for example, the case of the injunction under the New York privacy statute against a network broadcast scheduled for the day following the court decision. ${ }^{21}$ It may be, as has been suggested, that the injunction should have been denied on First Amendment grounds. In any event, deference to federal regulation would seem to require the plaintiff to wait until after the broadcast and then press his claim for damages. The reasons for this conclusion are similar to those which led the Court of Appeals for the Third Circuit to find that the Communications Act displaced the power of the states to censor movies scheduled to be shown on television. ${ }^{22}$ The Act makes clear that the FCC lias no such power of censorslip or prior restraint. With such authority expressly denied to the federal agency, it would be perverse to allow a state agency or court to exercise just such power. Thus, the court of appeals concluded, the survival of state censorship powers would interfere with the FCC's regulatory functions; "Program control was entrusted to the Federal Commission and it is an effective one. ${ }^{2223}$ An injunction against a network broadcast based on the tort law of a single state would seem to present a similar interference with the federal schenie and ought therefore to be refused on similar grounds. State injunctions against local broadcasting of certain matter may, of course, present different issues; the Head case involved, after all, a state court mjunction against the local dissemmation on a single station of local advertisements.

A second situation in which a partial immunity miglnt be recognized is that of punitive damages under state law. While the awarding of compensatory damages may make broadcasting less profitable, it may

221 Durgom v. CBS, 29 Misc. 2d 394, 214 N.Y.S.2d 752 (Sup. Ct. 1961).

222 Allen B. Dumont Labs, Inc. v. Carroll, 184 F.2d 153 (3d Cir. 1950).

223 Id. at 156 . 
not put many stations off the air. Punitive damages, however, could have just that effect. The sting of punitive damage awards would seem greatest in precisely those cases where the federal obligation to become involved in politics and controversy would be felt most heavily-the Mississippi station, for example, which presents a candid discussion of civil rights in order to save its license. The fact is that more than one small but courageous Southern newspaper has been seriously jeopardized by extravagant punitive damages growing out of racial issues. ${ }^{224}$ That fate should not be permitted to befall the broadcaster who enters the dangerous waters only to comply with a federal mandate to serve the public interest.

A third case warranting partial immunity may be that of criminal remedies. Some states still have criminal libel laws, although their permissible scope under the Constitution has been drastically curtailed by recent Supreme Court decisions. ${ }^{25}$ Other states have criminal sanctions against such invasions of privacy as the broadcast of the names of rape victims. ${ }^{226}$ Occasionally these sanctions have been applied to the broadcaster, apparently without consideration of their possible conflict with federal regulation. ${ }^{227}$ While a criminal prosecution for something said on the air may not put the station or its owner out of business, the sanction is still drastic. There are, moreover, several federal criminal laws which apply specifically to broadcasting. ${ }^{228}$ Their presence might suggest, even in the absence of actual conflict, a federal design to limit the broadcaster's criminal liability to those precise situations. If every state may superimpose its criminal sanctions on those of the federal law, fear of jeopardy may deter the broadcaster from entering the very areas on which serving the public interest places the greatest premium.

There are other situations in which the broadcaster may be partially relieved of liability. State statutes on privacy and on broadcast defamation vary considerably, as we have already observed. Writers have continually remarked upon the patchwork of liability that confronts

224 See Lyons, supra note 201, at 47. In addition, recent developments suggests another possible source of jeopardy for southern broadcasters who deal frankly with civil rights. A Bogalusa, Louisiana station claims it has been the victim of a sponsor boycott instigated by the Ku Klux Klan because of the station's participation in the sponsorship of an address by former U.S. Representative Brooks Hays to a racially mixed audience in Bogalusa. Although the address was cancelled, apparently because of community pressures and "intimidation," the station's sponsors soon fell from 75 to 6 . San Francisco Chronicle, April 6, 1965, p. 26, col. 4.

225 See Garrison v. Louisiana, 379 U.S. 64 (1964).

226 E.g., Ga. Code ANv. § 26-2105 (1953); S.C. Code ANv. \& 16-81 (1962). One such statute, WIs. Stat. ANN. $\S 942.02$ (1958), has been sustained against a constitutional challenge, in State v. Evjue, 253 Wis. 146, 33 N.W.2d 305 (1948).

227 Nappier v. Jefferson Standard Life Ins. Co., 322 F.2d 502 (4th Cir. 1963).

22818 U.S.C. $\S \S 1343,1464$ (1958). 
the interstate publisher. The broadcaster is in an even more perilous position because of the uncertainty as to which states will receive his signal on a particular day or at a given hour. Thus a strong argument for federal immunity can be made in the case, for example, of a cleared channel broadcaster whose federal license gives him a wide territory, if his programs reach a single distant state where material that is protected everywhere else has been made actionable. The one state that enacts bizarre laws on defamation or privacy or other communication torts ought not be empowered to stifle the broadcasting of material which is legal everywhere else. ${ }^{229}$ Of course, if the state that is out of line happens to be the home of the key station, substantially different questions are presented. For the moment we need go no further than to consider the reacl of a single deviant receiving state.

A strong case for an immunity can also be made out with regard to educational television (ETV). There have apparently been no tort suits against ETV stations yet. The liability of educational television may be affected by federal regulation in two distinct ways: For one, the FCC has been considerably more lenient with respect to the financial responsibility of ETV applicants than of commercial broadcasters. ${ }^{230}$ The purpose has been to encourage low-cost, non-profit presentation of material that would probably never be broadcast if it were forced to find commercial sponsors. Operation of this kind might be impossible if ETV clannels were subject to the same habilities as the commercial broadcaster. The other relevant aspect of federal regulation is the recent appropriation by Congress of substantial funds for the further development of educational television. The 1962 amendments to the Communications Act are designed to assist, on a matching grant basis, the "prompt and effective use of all educational television channels remaming and available" and to bring ETV to areas of the country which are not now served by this medium. ${ }^{231}$ The direct federal participation in this objective might be frustrated by heavy tort liability under state law, and some immunity might therefore be appropriate.

\section{A Uniform Federal Standard of Broadcaster Liability}

Even if federal law grants no general immunity to the broadcaster, it is possible that federal law requires the application of a uniform

229 An analogous limitation on state regulation of radio and TV advertising was suggested by Mr. Justice Brennan in Head v. New Mexico Bd. of Examiners in Optometry, 374 U.S. 424, 447 (1963) (concurring opinion); cf. Bibb v. Navajo Freight Lines, Inc., 359 U.S. 520 (1959). 1961).

230 See, c.g., NTA Television Broadcasting Corp., 22 Radio REg. 273, 291 (F.C.C.

$231 \S 392$ (d), added by 76 Stat. 65 (1962), 47 U.S.C. $\S 392$ (d) (Supp. V, 1964). 
standard of tort liability. The courts have so leld with respect to defamation claims against telephone and telegraph companies. ${ }^{232}$ The ground for this lolding is simply stated: "Congress having occupied the field by enacting a fairly comprehensive scheme of regulation, it seems clear that questions relating to the duties, privileges and liabilities of telegrapl companies in the transmission of interstate messages must be governed by uniform federal rules."233 It lias been suggested that similar reasonimg should establish a uniform federal standard of liability for the broadcaster. ${ }^{234}$

No court, lowever, has accepted the suggestion. It is not lard to see why. The cases of the telegrapher and the broadcaster are readily distinguishable, despite their responsibility to the same federal agency. The regulation of the telegrapher is vastly broader; the jurisdiction of the FCC covers many matters, such as the rates and conditions of service, on which the broadcaster is entirely autonomous. ${ }^{235}$ As a common carrier, the telegrapher needs the assurance and the predictability of a uniform federal standard for reasons that do not affect the broadcaster's business. ${ }^{236}$ Then, too, there is a history of oppressive state regulation of various aspects of telegraplyy which made the federal standard of liability almost a necessity. Moreover, the federal common law of defamation by telegraph was well developed when radio and the FCC were still in their infancy. Finally, the successive Congresses which lave rejected proposals for a federal immunity for the broadcaster seem to have simply assumed the continued applicability of the variable state law of defamation and related torts. ${ }^{237}$

On the other hand, the kaleidoscopic variations of tort law from state to state urge the enactment of a uniform federal broadcast defamation law. Suggestions lave been made in this direction, ${ }^{238}$ and the most

232 O'Brien v. Western Union Tel. Co., 113 F.2d 539, 541 (1st Cir. 1940); see Smith, Liability of a Telegraph Company for Transmitting a Defamatory Message, 20 CoLum. L. REv. 30, 369 (1920).

233 O'Brien v. Western Union Tel. Co., supra note 232 at 541.

234 See Berry \& Goodrich, Political Defamation: Radio's Dilemma, 1 U. FLA. L. REv. 343,352 (1948).

235 See Note, The Choice of Law in Maltistate Defamation and Invasion of Privacy, 60 HARv. L. REv. 941, 951 (1947).

236 See O'Brien v. Western Union Tel. Co., 113 F.2d 539, 541-42 (1st Cir. 1940).

237 See Brief for Petitioner, pp. 36-38, Farmers Educ. \& Coop. Union of America v. WDAY, Inc., 360 U.S. 525 (1959).

238 See, e.g., Keller, Federal Control of Defamation by Radio, 12 Notre DaMe Law. 15, 134 (1936-37); Korbel, Defamation by Broadcast: The Need for Federal Control, 49 A.B.A.J. 771 (1963); Snyder, Liability of Station Owners for Defamatory Statements Made by Political Candidates, 39 VA. L. Rev. 303, 317 (1953); Note, Multi-State Libel and Conflict of Laws, 35 Va. L. Rev. 627, 638-39 (1949); Note, Political Defamation by Radio and the Federal Communications Act, 46 Irr. L. Rev. 626, 635 (1951). 
recent proposal is expected to be introduced soon in the House of Representatives. ${ }^{239}$ There seems little doubt that Congress has power under the commerce clause to enact such legislation ancillary to its regulation of broadcasting. Years ago the courts upheld the federal statute that makes criminal certain obscene utterances on the air. ${ }^{240}$ There are numerous federal statutes that provide private remedies against other types of regulated defendants. ${ }^{241}$ These statutes, either expressly or by implication, establish uniform federal standards of liability which govern suits in the state as well as federal courts. The constitutionality of such statutes is widely assumed. One would be amazed today to find any serious doubt about congressional power respecting broadcast defamation. ${ }^{242}$

The more important question is wlat provisions such a federal law ouglit to contain. All that can be done liere is to list various matters that sliould be considered in the drafting process. Perliaps the first issue concerns the scope of such law, whether it should cover only the field now covered by state law of defamation, or should also supersede state privacy law (as to which the need for federal uniformity may be less pressing). Attention ought then to be given to the "single publication" problem. Undoubtedly an enlightened federal statute would incorporate the single publication principle, and accompany it with a reasonable limitation period essential to reinforce the principle of uniformity which might be frustrated if the timing of litigation were left to state limitation law.

There are other obvious matters that should be considered, such as the persons who are covered, or exempted from liability. The speaker, the broadcaster, the sponsor, the producer, the advertising agency and others might all be dealt with more explicitly than state statutes have yet done. As to each defendant, a standard of care ought to be prescribed, conditioned perhaps on certain factors. For example, there should be little doubt the speaker is always absolutely liable; perhaps the broadcaster could be held absolutely liable for the torts of an

239 See Broadcasting, March 8, 1965, p. 5.

240 Duncan v. United States, 48 F.2d 128 (9th Cir. 1931).

241 The decision of the Supreme Court in Second Employers' Liability Cases, 223 U.S. 1, 50 (1912), left little doubt that Congress had power under the commerce clause to regulate tort liability with respect to activities in interstate commerce. For other examples of the exercise of this power, see, e.g., 35 Stat. 65, as amended, 45 U.S.C. $\$ 51$ (1958) (Federal Employers Liability Act); 38 Stat. 731 (1914), 15 U.S.C. § 15 (1958) (Clayton Act) ; 48 Stat. 896 (1934), 15 U.S.C. \& 78p(b) (1958) (Securities Exchange Act).

242 See Friedenthal \& Medalie, The Impact of Federal Regulation on Political Broadcasting: Section 315 of the Communications Act, 72 HARv. L. REv. 445, 483-84 (1959); Korbel, supra note 238, at 772; McDonald \& Grimshaw, Radio Defamation, 9 AIR L. REv. 328, 340-41 (1938); Note, Defamation bv Radio, 33 VA. L. REv. 612, 620 (1947). 
employee, liable for lack of due care in the selection of a scheduled non-employee, and exempt in the case of a non-scheduled, non-employee over whom he liad no control. ${ }^{243}$

Privileges, defenses and immunities should also be dealt with. The principle of $W D A Y$, at least, should be codified. And some thought should be given to some of the partial immunities discussed above in the broadcasts compelled or dictated largely by federal law. The matter of privileges might require more detail than the legislation is worth, and because of the degree of uniformity that prevails in existing state law, could perliaps be resolved by incorporating the applicable state law by reference into the federal standards. On the other hand, it may be that the federal common law developed in the telegraph and telephone cases would be more suitable for this purpose. The question of retraction should not be overlooked. It seems unlikely that any method of retraction could be devised that would be as effective as in newspaper libel. In its place it might be appropriate to adopt some form of the "right of reply" which has been used so successfully in many European countries.

Some consideration should also be given to procedure and remedies. Suits under the statute could perhaps be confined to the federal courts, although there would seem no reason to exclude the state courts. A more difficult question would arise with respect to an administrative remedy. Some federal regulatory statutes give the agency power to award damages, and the FCC already has such power with respect to certain violations of the Act's express provisions. ${ }^{244}$ More thought would have to be given before deciding whether to extend that power to violations of this proposed new law. Other remedial problems would arise with respect to the damages that can be recovered, and specifically whether a broadcaster ought to be immune from punitive damages, at least where he has acted in accordance with the obligations of his license. Finally,

243 A suggestion might be to cover the case of a broadcaster who is neither insured nor solvent at the time of a judgment against him by establishing a federal indemnity fund to compensate the plaintiff who proves his case but has no other recourse. See Note, Censorship of Defamatory Political Broadcasts: The Port Huron Doctrine, 34 N.X.U.L. REv. 127, $140 \mathrm{n.77}$ (1959). The claims on such a fund would be infrequent in view of the FCC's solicitude for the solvency of broadcasters, and the number of other potential defendants in almost every case. The cost of such a fund would seem a small price for the assurance that every case will be covered.

244 Under § 207, 48 Stat. 1073 (1934), 47 U.S.C. \& 207 (1958), the FCC shares with the federal district courts jurisdiction over complaints and suits for damages against common carriers subject to the Commumications Act, based upon alleged violations of the Act. The term "common carrier" excludes licensed radio and television broadcasters, with the result that no provision is made in the Act for recovery of damages from broadcasters on any ground. 
there should be some consideration given to criminal penalties. Although many of the proposed federal broadcast defamation bills have included criminal sanctions, it has not been shown that civil remedies would be inadequate. Criminal libel laws are always suspect, ${ }^{245}$ and unless compelling reason appears for their inclusion, an enlightened federal law would seem happily rid of them. The federal prohibitions of obscenity, fraud and the like on the air would presumably remain, lowever, for they raise less serious questions under the first amendment.

\section{The Broadcaster and the Law of Unfair Competition}

Any discussion of the effect of federalism upon the broadcaster's tort liability would be incomplete without some mention of unfair competition. The problem arises because state and federal law afford sometimes overlapping, or even conflicting, protections to certain interests-principally to the broadcasts themselves or the subject matter of the broadcasts. The conflict arises not only from the interaction of state law with the Communications Act, but also with the federal Copyright Act. These conflicts are rapidly becoming acute with the growth of cominunity antenna television.

Piracy of radio broadcasts has been a major problem almost since the beginning of commercial broadcasting. The cases have fallen into three general categories: First, there has been the actual appropriation by one broadcaster of the raw material or actual subject matter to which a competitor has acquired exclusive broadcasting riglits. For example, the pirate station may send a scout into a baseball park, or position him atop the fence of a racetrack to gather information from which to broadcast the results of the event without permission of the proprietor or of the competing station. Several such cases have resulted in injunctions against such allegedly unfair competition. ${ }^{246}$

A second kind of piracy involves the use of the actual broadcast in competition with the hive event. For example, the promoters of a inajor boxing match or professional football game will often insist upon a "blackout" in the vicinity of the event to increase the revenue at the gate. ${ }^{247}$ Alternatively, they may grant exclusive riglits via closed circuit

245 See Garrison v. Louisiana, 379 U.S. 64 (1964).

240 E.g., Pittsburgh Athletic Co. v. KQV Broadcasting Co., 24 F. Supp. 490 (WD. Pa. 1938); Twentieth Century Sporting Club, Inc. v. Transradio Press Serv., Inc., 165 Misc. 71, 300 N.Y. Supp. 159 (Sup. Ct. 1937) ; Victoria Park Racing \& Recreation Grounds Co. v. Taylor, [1937] Argus L.R. 597. But cf. National Exhibition Co. v. Teleflash, Inc., 24 F. Supp. 488 (S.D.N.Y. 1936).

247 The FCC has recently suggested that the "blackout" practice may be contrary to the pubhc interest because it deprives an important segment of the viewing and listening audience of immediate access to sporting events which they cannot personally attend. Paducah Newspapers, Inc., 1 Radio Reg. 2d 987 (FCC 1964). 
TV to one or more local movie theaters, permitting general radio and television coverage only beyond a 100 mile radius. These arrangements do not always prevent theaters and taverns with powerful antennas from picking up the signal from outside the blackout area and piping the broadcast in for the benefit of their patrons. In the few such cases that have arisen, the courts have generally granted relief on grounds of unfair competition. ${ }^{248}$

The third type of piracy is more recent and more complex. With the advent of community antenna television, there has been substantial appropriation of network material from distant stations (by means of tall and powerful antennas) which is then relayed to subscribers, in competition with local stations that have network contracts for the broadcast of the same material. The courts have just begun to deal with this problem, and the results are still inconclusive. ${ }^{240}$ The uncertainty is compounded by the FCC's reluctance to assert jurisdiction over community antenna systems. ${ }^{250}$

\section{Preemption Under the Communications Act}

The application of state law of unfair competition to suits such as these might be preempted by either of two bodies of federal law. First, and less likely, there is a section of the Federal Communications Act which forbids any broadcasting station to "rebroadcast the program or any part thereof of another broadcasting station without the express authority of the originating station."251 This provision facilitates net-

248 E.g., CBS v. Circle Bar \& Grill, Inc., 20 Radio Reg. 2128 (N.J. Super. Ct. 1960); cf. Mutual Broadcasting Sys. v. Muzak Corp., 177 Misc. 489, 30 N.Y.S.2d 419 (Sup. Ct. 1941). In this connection it should be noted that the power of the states to regulate the reception of television programs in public places such as bars and tap rooms, usually by requiring special entertainment permits, has generally been sustained. See Mosey Cafe, Inc. v. Helena Television, Inc., 125 U.S.P.Q. 595 (Mont. Dist. Ct. 1960); cf. Jackson v. $364 \mathrm{~Pa}$. 361, 72 A.2d 85 (1950).

240 See Cable Vision, Inc. v. KUTV, Inc., 335 F.2d 348 (9th Cir. 1964); Z Bar Net, Inc. v. Helena Television, Inc., 125 U.S.P.Q. 595 (Mont. Dist. Ct. 1960); cf. Jackson v. Hayward, 9 Utal 2d 136, 339 P.2d 1026 (1959). Many of the recent proceedings and other developments in the CATV field are discussed in Note, Community Antenna Television: Survey of a Regulatory Problem, 52 Geo. L.J. 136 (1963). One other case pertinent to this discussion is Loeb v. Turner, 257 S.W.2d 800 (Tex. Civ. App. 1953), in which the court refused to enjoin one broadcaster's "recreation" of a stock car race in another state, which was based upon a running commentary telephoned to the station by an agent who was listening to the plaintiff's authorized broadcast from the racetrack.

250 It now appears that FCC regulation of community antenna systems is imminent, although the terms and conditions of regulation are of course subject only to speculation. See Broadcasting, March 29, 1965, p. 5; April 19, 1965, p. 60. Sec generally discussion note 122 supra.

251 \& $325(a), 48$ Stat. 1091 (1934), 47 U.S.C. \& 325(a) (1958). 
work broadcasting by giving to the network's key or originating station a limited monopoly in all its broadcasts. ${ }^{252}$

It can be argued that this section displaced all state unfair competition law covering the same area. The contrary arguments seem overwhelming, however. The statute prohibits only an appropriation by another "broadcaster." Thus it clearly does not cover the case of the theatre or tavern which picks up a broadcast and exploits it for profit in the "blackout" region. Nor does it seem to apply to the community antenna situation, because the community antenna service has never been considered a "broadcaster" within the meaning of the Act. ${ }^{253}$ The one court which has considered this question concluded, therefore, that "community antenna services ... are not required by the Act as presently written to obtain the consent of a broadcasting station before picking up its signal and its programs."

There remains the third case, that of the pirate station which peeks through the sports-arena keyhole or sets up a fence-top booth overlooking the racetrack. Here the defendant clearly is a "broadcaster." But the statute still seems inapplicable because the misappropriation, albeit in competition with another broadcaster, is not the rebroadcasting of "the program or any part thereof of another broadcasting station ...." Thus by consideration of each of the cases to which it might apply, it would seem that nothing in the Communications Act displaces state law in unfair competition suits of this type involving broadcasters.

\section{Preemption Under the Copyright Act}

The possible preemptive effect of the federal copyright laws presents a much harder question. A broadcaster's rights in his material, if legally unpublished, may of course rest on a common law copyright. It is quite clear that nothing in the federal law precludes the assertion of claims based upon the common law copyright. ${ }^{255}$ But there is increasing doubt whether a radio or TV broadcast heard or seen by millions should be considered "unpubhished,"

252 See Developments in the Law-Competitive Torts, 77 HaRv. L. Rev. 888, 946 (1964). 203 See Note, 52 Geo. L.J. 136, 143 (1963).

204 Cable Vision, Inc. v. KUTV, Inc., 211 F. Supp. 47, 55 (D. Idaho 1962), vacated and remanded on other grounds, 335 F.2d 348 (9th Cir. 1964).

205 Copyright Act, \& 2, 17 U.S.C. § 2 (1958); see Sears, Roebuck \& Co. v. Stiffel Co., 376 U.S. 225, 231 n.7 (1964),

250 See Krasnow, Copyrights, Performers Rights and the March on Civil Rights: Reflections on Martin Luther King, Jr. v. Mister Maestro, 53 GEo. L.J. 403, 416-19 (1965); Selvin, Should Performance Dedicate?, 42 CalrF. L. Rev. 40 (1954).

257 Uproar Co. v. NBC, 8 F. Supp. 358 (D. Mass. 1934), aff'd, 81 F.2d 373 (1st Cir.), cert. denied, 298 U.S. 670 (1936); King v. Mister Maestro, Inc., 224 F. Supp. 101, 106-07 (S.D.N.Y. 1963); CBS v. Documentaries Unlimited, Inc., 42 Misc. 2d 723, 248 N.Y.S.2d 
The difficult question, then, is how far the federal copyright laws preempt the state law of unfair competition in suits between or involving broadcasters. It seems quite clear, at one extreme, that states may not protect material which has been published, but without an attempt to secure federal copyright protection. This conclusion rests upon a basic principle that once the term of federal statutory protection has expired, the states are powerless to extend that term under the common law. ${ }^{258}$

Until 1964, however, there was considerable doubt about the application of this principle to material which was theoretically entitled to federal protection but for some reason was not in fact protected. Last year the Supreme Court decided two cases involving manufactured articles which had been held unpatentable for lack of invention. Competitors of the manufacturers had produced and marketed "chinese copies" of the articles. Applying the state law of unfair competition, the lower federal courts enjoined further sale of the copies. ${ }^{260}$ The Supreme Court unanimously reversed, however, in Sears, Roebuck $\mathcal{E}^{\circ}$ Co. v. Stiffel Co., ${ }^{260}$ and Compco Corp. v. Day-Brite Lighting, Inc. ${ }^{201}$ Mr. Justice Black, writing for the Court, observed that the patent laws, by conferring a limited monopoly on the inventor, had struck a balance between rewarding the creator and preserving free competition. State law could not frustrate or upset that balance. Thus, "to allow a State by use of its law of unfair competition to prevent the copying of an article which represents too slight an advance to be patented would be to permit the State to block off from the public something which federal law has said belongs to the public. . . . This would be too great an encroachment on the federal patent system to be tolerated."282

Unquestionably these principles apply as much to copyright as to patent protection. ${ }^{263}$ Presumably, therefore, state unfair competition law may not protect works for which federal copyright is available but has not been obtained. But what of those works which fall within the

809,811 (Sup. Ct. 1964). These cases are based upon the old leading case of Ferris v. Froliman, 223 U.S. 424 (1912), which held that the public performance of a play, no matter how often repeated, did not constitute a publication divestitive of common law copyright.

258 See Merriam v. Holloway Pub. Co., 43 Fed. 450 (C.C.E.D. Mo. 1890); cf. G. Ricordi Co. v. Haendler, 194 F.2d 914 (2d Cir. 1952).

259 Stiffel Co. v. Sears, Roebuck \& Co., 313 F.2d 115 (7th Cir. 1963); Day-Brite

Lighting Co. v. Compco Corp., 311 F.2d 26 (7th Cir. 1962).

260376 U.S. 225 (1964).

261376 U.S. 234 (1964).

262376 U.S. at $231-32$.

203 The Court so indicated at several places in its two opmions. See 376 U.S. at 231 n.7, 232-33. 
constitutional term "writings of an author" for which Congress has made no provision in the Copyright Act? One author has argued that "Congress' failure to provide protection should be interpreted as a decision that there be no protection at all." ${ }^{264}$

This argument might suggest that state unfair competition protection is unavailable even for radio and TV broadcasts which are not within the Copyright Act. It seems unlikely, however, that the Supreme Court's recent decisions go so far. For in those cases the Court carefully restricted its holding to articles that were not only covered by the Patent Act, but for which patent protection had been sought and denied. To extend that principle to the articles, or "writings" for which no statutory protection is even theoretically available, would create a "no-man's land" which is generally abhorrent to federal law. ${ }^{265}$ This extension would leave the broadcaster remediless except to the limited extent that the present interpretation of the Copyright Act, augmented by the Communications Act, may afford statutory protection.

We have assumed to this point that statutory protection is unavailable for radio and TV broadcasts. It may be, however, that through the medium of the videotape, copyright protection can be claimed for much of the broadcaster's hiterary product. ${ }^{266}$ This would be the case whether or not the showing of the tape is considered to be a "publication," for federal copyright protection is available both for published and unpublished works. Thus it may develop that the broad preemption issue, the issue left open by the Supreme Court in Sears and Compco, may not have to be reached because statutory copyright protection is after all available to the broadcaster.

Several courts have already considered these questions since the Suprenie Court's decision. Probably the most significant case is the Ninth Circuit Court of Appeals' decision in the first major community antenna TV case. ${ }^{267}$ The case originated as an antitrust suit brought by the CATV proprietor against the network station which had exclusive broadcasting rights for a section of Idaho. The station counterclaimed and requested an injunction on grounds of unfair conpetition and "tortious interference" under state law. The district court, prior

264 Developments in the Law-Competitive Torts, 77 HARV. L. Rev. 888, 943-44 (1964); compare Waring v. WDAS Broadcasting Station, Inc., $327 \mathrm{~Pa} .433,194$ Atl. 631 (1937), with RCA Mfg. Co. v. Whiteman, 114 F.2d 86 (2d Cir.), cert. denied, 311 U.S. 712 (1940). 265 Cf. Head v. New Mexico Bd. of Examiners in Optometry, 374 U.S. 424, 446-47 (1963) (concurring opinion).

260 See Fritch, Some Copyright Implications of Videotapes, 37 So. CaL. L. REv. 214 (1964).

267 Cable Vision, Inc. v. KUTV, Inc., 335 F.2d 348 (9th Cir. 1964)، 
to Sears and Compco, granted relief on the counterclaim. ${ }^{268}$ The court of appeals reversed, after the Supreme Court's decisions, ${ }^{269}$ holding that unless the TV station could slow that its interests were protected by the copyright laws, or could invoke "some other recognized exception to the policy promoting free access to all matter in the public domain," no relief could be granted on the counterclaim..$^{270}$ In this counterclaim, the court of appeals found precisely that use of state unfair competition law that the Sears and Compco decisions liad foreclosed. ${ }^{271}$ Since neither deception nor passing off liad been alleged as the basis of the unfair competition, the counterclaim simply duplicated the protections theoretically afforded by the federal statutory scheme.

Since the Ninth Circuit's decision there liave been two other cases, both in New York. The first of these involved an unautliorized use, for the production of a commercial plonograpl record, of CBS news commentator Allan Jackson's moving report of the death of President Kennedy. Jackson and the network both sued the recording company, seeking damages and an injunction for alleged infringement of commonlaw copyriglit and for unfair competition. The court granted relief on both grounds. ${ }^{272}$ Both Sears-Compco and the community antenna TV case were distinguislred, easily on the copyright count, and on the unfair coinpetition count only after finding evidence of the very kind of deception or passing off that had been lacking in the earher cases.

The other New York case went off on uncertain procedural grounds. ${ }^{273}$ But the court did recognize that in the absence of any copyriglit claim, deception or passing off must be slown to bring the

268211 F. Supp. 47 (D. Idaho 1962).

200335 F.2d 348 (9th Cir. 1964). Sears and Compco were decided in March; Cable Vision in mid-July of 1964 .

270335 F.2d at 354.

271 The court stressed the narrowing effect of Sears and Compco on the state law of unfair competition: "Save for the limited protection accorded the creator of literary and intellectual works under the Copyright Act or its exceptions ... . anyone may freely and with impurity avail himself of such works to any extent he may desire and for any purpose whatever subject only to the qualification that he does not steal goodwill, or, perhaps more accurately stated, deceive others in thinking the creations represent his own work." 335 F.2d at 351 .

272 CBS v. Documentaries Unlimited, Inc., 42 Misc. 2d 723, 248 N.Y.S.2d 809 (Sup. Ct. 1964); cf. King v. Mister Maestro, Inc., 224 F. Supp. 101 (S.D.N.Y. 1963). But cf. Bupp v. Great Western Broadcasting Corp., 201 Cal. App. 2d 580, 20 Cal. Rptr. 106 (1962), refusing damages for a TV station's use during a strike of videotaped announcements recorded for the station by the plaintiff announcer prior to the strike.

273 Flamingo Telefilm Sales, Inc. v. United Artists Corp., 22 App. Div. 2d 778, 254 N.Y.S.2d 36 (1964). The court refused to enjom alleged misappropriation of exclusive rights claimed by the plaintiffs to hicense the showing of certain movies on television. For an early discussion of this problem, see Silverberg, Televising Old Films-Some New Legal Questions About Performers' and Proprietors' Rights, 38 VA. L. REv. 615 (1952). 
case within that segment of unfair competition law that survived the Sears and Compco decisions. That is where the matter rests for the moment.

\section{CONCLUSION}

It is still too early to judge the net effect upon the broadcaster of the convergence of these two major hines of legal development. At most, it can confidently be stated that both are profoundly important for the radio and television industry. On the one hand, the character of tort litigation affecting the broadcaster is changing, and appears to be increasingly threatening. Invasion of privacy and competitive tort suits are bound to become more important, whether or not defamation diminishes in significance. On the other hand, the broadcaster's claim for at least partial immunity under federal law never rested on a firmer legal foundation. Both the first amendment and the Communications Act, in quite distimct ways, suggest many situations in which new defenses may be available to the broadcaster. What these developments underscore is a need for careful analysis, especially of the relationship of the two lines of cases to one another. On the basis of sucli analysis, there may be fruitful possibilities for new legislation. At the very least, the problems that are likely to come before the courts in the next decade may be more clearly understood. 
